Check for updates

Cite this: RSC Adv., 2018, 8, 34984

Received 10th June 2018

Accepted 5th October 2018

DOI: $10.1039 / c 8 r a 04956 d$

rsc.li/rsc-advances

\section{Dual function of molybdenum sulfide/C-cloth in enhancing the performance of fullerene nanosheets based solar cell and supercapacitor $\dagger$}

\begin{abstract}
Aparajita Das, ${ }^{a}$ Melepurath Deepa (D) *a and Partha Ghosal ${ }^{b}$
Quantum dot solar cells (QDSCs) with hexagonal fullerene nanosheets ( $\left.\mathrm{C}_{60}-\mathrm{NS}\right)$ embedded in a titanium oxide/ cadmium sulfide $\left(\mathrm{TiO}_{2} / \mathrm{CdS}\right)$ photoanode coupled with a carbon-cloth (C-cloth) coated with molybdenum sulfide $\left(\mathrm{MoS}_{2}\right.$ ) counter electrode (CE) are studied for the first time. $\mathrm{C}_{60}$-NS due to a favorable work function of $4.57 \mathrm{eV}$ and a conductance of $1.44 \mu \mathrm{S}$, enable faster electron injection from the conduction band of cadmium sulfide to the current collector, in contrast to the bulk fullerene based $\mathrm{TiO}_{2} / \mathrm{CdS}$ solar cell. The champion cell with the $\mathrm{TiO}_{2} / \mathrm{C}_{60}$-NS/CdS photoanode and a $\mathrm{MoS}_{2} / \mathrm{C}$-cloth $\mathrm{CE}$ exhibits a high power conversion efficiency of $5.6 \%$, greater by $\sim 14 \%$ relative to its' analogue cell with bulk fullerene. A large area cell of $1 \mathrm{~cm}^{2}$ dimensions with $\mathrm{TiO}_{2} / \mathrm{C}_{60}-\mathrm{NS} / \mathrm{CdS}$ gives a PCE of $2.9 \%$. The effect of $\mathrm{MoS}_{2}$ in improving the efficiency of the cell with a $\mathrm{TiO}_{2} / \mathrm{C}_{60}-\mathrm{NS} / \mathrm{CdS}$ photoanode is realized in terms of enhanced electrocatalytic activity for polysulfide reduction, and lower charge transfer resistance at the polysulfide/CE interface compared to a cell with the same photoanode but having pristine carbon-cloth as the CE. The ability of $\mathrm{MoS}_{2}$ for catalyzing the oxidized polysulfide species at the $\mathrm{CE}$ and $\mathrm{C}_{60}-\mathrm{NS}$ for improving the charge collection at the photoanode serve as indicators for their wider utilization in solar cells. It also serves as a good supercapacitor material. A MoS $/$ C-cloth based symmetric cell exhibits a specific capacitance of $645 \mathrm{~F} \mathrm{~g}^{-1}$ at $2 \mathrm{~A} \mathrm{~g}^{-1}$, which shows its' potential for energy storage as well. By integrating the QDSC and the supercapacitor, the resulting integrated device acquires a photovoltage of $0.7 \mathrm{~V}$, under 1 sun illumination.
\end{abstract}

\section{Introduction}

In recent years, quantum dot solar cells (QDSCs) have scaled very high power conversion efficiencies, greater than $12 \%,{ }^{\mathbf{1 , 2}}$ thus propelling them to the forefront of photovoltaic (PV) research. Quantum dots (QDs) are characterized by band gap tunability, multiple exciton generation, low cost and high extinction coefficient; the former three properties are not available to Ru-dyes typically used in dye sensitized solar cells (DSSCs), the analogues of QDSCs. ${ }^{3}$ These benefits of QDs provide the impetus to apply them in PV cells. Among the various visible and/or near infrared (NIR) light absorbing QDs, such as CdS, ${ }^{4} \mathrm{CdSe},{ }^{5} \mathrm{PbS}^{6}$ and $\mathrm{CuInS}_{2},{ }^{7}$ which have been used in QDSCs in the past, CdS QDs absorb the blue-green region of the solar spectrum, they are cheap, and films of CdS can be easily

\footnotetext{
${ }^{a}$ Department of Chemistry, Indian Institute of Technology Hyderabad, Kandi-502285, Sangareddy, Telangana, India. E-mail: mdeepa@iith.ac.in

${ }^{b}$ Defence Metallurgical Research Laboratory, DRDO, Hyderabad 500058, Telangana, India

$\dagger$ Electronic supplementary information (ESI) available: Cyclic voltammetry of pristine $\mathrm{TiO}_{2}$ and CdS, XRD and Raman spectra of $\mathrm{MoS}_{2}$, C-cloth and $\mathrm{MoS}_{2}$ /C-cloth, tables of emission decay fitting parameters of photoactive films, Raman and EIS data of counter electrodes, solar cell parameters of large area (1 $\mathrm{cm}^{2}$ ) QDSCs using $\mathrm{MoS}_{2} / \mathrm{C}$-cloth CE and stability performance of QDSCs at 100 min interval of time. See DOI: 10.1039/c8ra04956d
}

deposited over the wide gap semiconductor $\left(\mathrm{TiO}_{2}\right)$ by using simple methods at room temperature, without any expensive equipment or complex reaction conditions of temperature or pressure or inert atmosphere. Charge collection at the photoanode is improved by the use of passivation layers like $\mathrm{ZnS}$, $\mathrm{ZnSe}, \mathrm{SiO}_{2}$, and amorphous a-TiO${ }_{2}$, and their combinations. ${ }^{8-10}$ These layers reduce charge recombination between photoanode and electrolyte and within the photoanode. Zhong's group achieved a PCE of $9.48 \%$ for CdSeTe/CdS quantum dot solar cells by applying a passivation layer of $\mathrm{SiO}_{2}$ and $\mathrm{a}-\mathrm{TiO}_{2} \cdot{ }^{11}$ Recently, for a cell with alloyed $\mathrm{Cu}-\mathrm{In}-\mathrm{Ga}-\mathrm{Se}$ QDs coated with a $\mathrm{ZnS}$ and $\mathrm{SiO}_{2}$ barrier layer, a high PCE of $11.6 \%$ was achieved with a titanium mesh/carbon based counter electrode (CE) ${ }^{\mathbf{1 2}}$ Besides the use of passivation layers, other strategies adopted in PV literature involve the incorporation of electrically conducting carbonaceous nanostructures such as graphene, ${ }^{13}$ fullerene $\left(\mathrm{C}_{60}\right){ }^{14}$ carbon nanotubes $(\mathrm{CNTs})^{\mathbf{1 5}}$ in the photoanode, to increase electron transport, minimize recombination and improve photocurrents. Fullerene, due to a high carrier mobility and a work function of $4.3 \mathrm{eV},{ }^{16}$ is widely used as an electron acceptor in organic photovoltaic cells, ${ }^{17}$ and therefore it can be applied to photoanodes of QDSCs as well, to promote electron transport to the current collector. ${ }^{\mathbf{1 4}}$

In addition to the photoanode, $\mathrm{CE}$ is a vital component of a QDSC. It collects electrons from external circuit and catalyzes 
the reduction of oxidized species of the polysulfide electrolyte, during cell operation. An ideal CE should be cost effective, electrically conductive, chemically stable and electrocatalytically active. Carbonaceous materials such as carbon, CNT and RGO etc., metal sulfides and selenides are observed to fulfil these requirements, and have been used in QDSCs in the past. $^{18-24}$

Among metal chalcogenides, $\mathrm{Cu}_{2} \mathrm{~S}$ is the most commonly used $\mathrm{CE}$ catalyst for polysulfide reduction, due to its' high electrocatalytic activity and chemical stability, but one of the objectives in this study is to prepare and use an equally effective alternate CE, that can also double up as an supercapacitor electrode. $\mathrm{MoS}_{2}$, satisfies these pre-requisites. While $\mathrm{MoS}_{2}$ is shown to be a powerful electrocatalyst for hydrogen production, ${ }^{25}$ it has been used rarely as a CE in QDSCs ${ }^{26}$ and DSSCs. ${ }^{27}$ It is relatively less explored as a CE in QDSCs, compared to the exhaustively studied $\mathrm{Cu}_{2} \mathrm{~S}$. It also shows good catalytic activity for polysulfide reduction, and is very stable in the polysulfide electrolyte. It is also easily processable in the form a uniform coating over the current collector (C-cloth), through a direct one-pot, in situ preparation cum deposition method. This method establishes a strong ohmic contact between $\mathrm{MoS}_{2}$ and C-cloth, and therefore electron delivery to $\mathrm{MoS}_{2}$ and electron extraction from $\mathrm{MoS}_{2}$ are rendered facile, during chargedischarge process, in the supercapacitor. Furthermore, $\mathrm{MoS}_{2}$ is capable of storing and releasing charge through an electrical double layer mechanism and a faradaic redox reaction. The structure of $\mathrm{MoS}_{2}$ is composed of three atom layers: a Mo layer sandwiched between two $S$ layers, and the triple layers are stacked repetitively and held together by van der Waal's forces. The layered structure of $\mathrm{MoS}_{2}$ furnishes a large number of accessible electrochemically active sites, which maximizes the ion ingress from the electrolyte during charging. Due to the aforementioned reasons, $\mathrm{MoS}_{2}$ is chosen to be the CE, in this report.

Tai et al., demonstrated a DSSC with a CE composed of a few layers of $\mathrm{MoS}_{2}$-nanosheets (NS) anchored on multiwalled carbon nanotubes (MWCNTs) with high electrical conductivity and electrocatalytic activity, and the corresponding PCE was $6.45 \% .^{28}$ Seol et al., used a Mo-compound/CNT-graphene composite based CE in a QDSC, and a PCE of 5.41\% was achieved. ${ }^{29} \mathrm{MoS}_{2}$ besides being used as a CE in solar cell, is also widely used in supercapacitors as an energy storage electrode, due to its high surface area, high electrical conductivity and high storage capacity. Ma et al., reported a poly(pyrrole)/MoS nanocomposite based supercapacitor and it showed a high specific capacitance of $553.7 \mathrm{~F} \mathrm{~g}^{-1}$ at a current density of $1 \mathrm{~A} \mathrm{~g}^{-1} .^{30}$ Huang et al., synthesized poly(aniline)/MoS $\mathrm{M}_{2}$ which gave a specific capacitance of $575 \mathrm{~F} \mathrm{~g}^{-1}$ at $1 \mathrm{~A} \mathrm{~g}^{-1} \cdot{ }^{31}$ They also developed a layered $\mathrm{MoS}_{2}$-graphene composite, which showed a capacitance of $243 \mathrm{~F} \mathrm{~g}^{-1}$ at a discharge current density of $1 \mathrm{~A} \mathrm{~g}^{-1} \cdot{ }^{32}$ The performance was attributed to a $3 \mathrm{D} \mathrm{MoS}_{2}$-graphene interconnected conductive network which promotes not only efficient charge transport and facilitates electrolyte diffusion, but also prevents effectively the volume expansion/ contraction and aggregation of electroactive materials during the charge-discharge process.

Here, we report the fabrication and characterization of a QDSC with a $\mathrm{TiO}_{2} / \mathrm{C}_{60}-\mathrm{NS} / \mathrm{CdS}$ photoanode, a $\mathrm{MoS}_{2} /$ carbon (C)- cloth $\mathrm{CE}$ and a polysulfide gel as the hole transport layer. $\mathrm{C}_{60}-\mathrm{NS}$ are prepared by liquid-liquid interfacial precipitation method and anchored to the $\mathrm{TiO}_{2}$ layer, and CdS QDs are deposited by successive ionic layer adsorption and reaction (SILAR). The role of the $\mathrm{C}_{60}-\mathrm{NS}$ in ameliorating charge transfer and transport is studied by comparing the cell with control cells with $\mathrm{TiO}_{2} / \mathrm{C}_{60}-\mathrm{B}$ (bulk)/CdS/ZnS and $\mathrm{TiO}_{2} / \mathrm{CdS} / \mathrm{ZnS}$ photoanodes. The role of $\mathrm{MoS}_{2}$ in improving cell performance is evaluated by comparing cell configurations having the same photoanode, but different CEs: pristine C-cloth and $\mathrm{MoS}_{2} / \mathrm{C}$-cloth. Based on the findings reported here, $\mathrm{MoS}_{2}$ and $\mathrm{C}_{60}$-NS can be applied to other cell configurations for improving cell response. The ability of $\mathrm{MoS}_{2} /$ C-cloth to function as an energy storage material is also explored, by studying its' capacitive characteristics. In addition, the performance of an integrated device comprising of an electrically connected QDSC and the supercapacitor are presented.

\section{Experimental}

\subsection{Chemicals}

$\mathrm{TiO}_{2} \mathrm{P} 25$ powder was a free gift from Evonik. Cadmium acetate $\left(\mathrm{Cd}\left(\mathrm{CH}_{3} \mathrm{COO}\right)_{2}\right)$, sodium sulfide $\left(\mathrm{Na}_{2} \mathrm{~S}\right)$, fullerene $\left(\mathrm{C}_{60}\right)$, molybdenum oxide $\left(\mathrm{MoO}_{3}\right)$, thioacetamide, methanol, isopropanol and acetyl acetone were procured from Aldrich. Ammonium fluoride $\left(\mathrm{NH}_{4} \mathrm{~F}\right)$, carbon tetrachloride $\left(\mathrm{CCl}_{4}\right)$, ethanol, acetone, titanium tetrachloride $\left(\mathrm{TiCl}_{4}\right)$, oleic acid, Triton X-100 were obtained from Merck. Fluorine-doped tin oxide coated glass substrates (FTO, resistivity $\sim 15 \Omega \mathrm{sq}^{-1}$ ) were obtained from Pilkington. Deionized water with a resistivity of $\sim 18.2 \mathrm{M} \Omega \mathrm{cm}$ was obtained from a Millipore Direct-Q3 UV system. C-cloth with a sheet resistance of $10 \Omega \mathrm{cm}^{-2}$ was procured from Alibaba Pvt. Ltd. Fumed silica $\left(\mathrm{SiO}_{2}\right)$ was a free gift from Cabot Corporation.

\subsection{Synthesis of $\mathrm{C}_{60}$ nanosheets and photoanode(s) fabrication}

$\mathrm{C}_{60}$-NS were prepared by using liquid-liquid interfacial precipitation method reported by Sathish et al. ${ }^{33} 0.1 \mathrm{~g}$ of $\mathrm{C}_{60}$ powder was dissolved in $25 \mathrm{~mL}$ of $\mathrm{CCl}_{4}$ followed by ultrasonication for $30 \mathrm{~min}$ and a purple colored solution was obtained. Then the final solution was filtered to remove the undissolved $\mathrm{C}_{60}$ powder. $1 \mathrm{~mL}$ of the $\mathrm{C}_{60}$ saturated solution was taken in a clean glass vial and kept in an ice water bath, maintaining temperature to $5{ }^{\circ} \mathrm{C}$. In a separate vial, $6 \mathrm{~mL}$ of isopropyl alcohol (IPA) was taken and maintained at the same temperature. When both solutions were in $5{ }^{\circ} \mathrm{C}$, IPA was added slowly to the $\mathrm{C}_{60}$ solution. The mixture was kept for $5 \mathrm{~min}$ at $5{ }^{\circ} \mathrm{C}$ without any disturbance. It was ultrasonicated for $5 \mathrm{~min}$ and then stored in $5{ }^{\circ} \mathrm{C}$ for $24 \mathrm{~h}$. The color of the solution was pale yellow color, which signaled the formation of $\mathrm{C}_{60}$-nanosheets (NS). This solution was directly used for preparing films. $\mathrm{C}_{60}$-bulk (B) solution was prepared by adding $6 \mathrm{~mL}$ of $\mathrm{CCl}_{4}$ solvent to $1 \mathrm{~mL}$ of the $\mathrm{C}_{60}$ saturated solution.

Over a cleaned FTO film, a $\mathrm{TiO}_{2}$ paste was applied by doctor blade method. $\mathrm{TiO}_{2}$ paste was prepared by dispersing $\mathrm{TiO}_{2}$ powder in a solution of acetyl acetone $(1.5 \mathrm{~mL})$, deionized water $(8.5 \mathrm{~mL})$ and Triton-X $100(20 \mathrm{mg})$ followed by sonication for 
$15 \mathrm{~min}$. It was applied on FTO, dried for $30 \mathrm{~min}$ at $60{ }^{\circ} \mathrm{C}$ in oven and annealed for $30 \mathrm{~min}$ at $500{ }^{\circ} \mathrm{C}$. One more layer was applied using the same process. The $\mathrm{TiO}_{2}$ film was immersed in a $0.04 \mathrm{M}$ aqueous $\mathrm{TiCl}_{4}$ solution, maintained at $70{ }^{\circ} \mathrm{C}$ for $30 \mathrm{~min}$ and rinsed in a deionized water followed by annealed at $500{ }^{\circ} \mathrm{C}$ for $30 \mathrm{~min}$ to obtain the final layer.

A solution of $\mathrm{C}_{60}-\mathrm{NS}(0.57 \mathrm{mg}$ in $1 \mathrm{~mL})$ was drop cast on a $\mathrm{TiO}_{2} /$ FTO film and rinsed in a $\mathrm{CCl}_{4} / \mathrm{IPA}$ solvent mixture and dried at ambient temperature. The same procedure was used for coating the $\mathrm{C}_{60}$-B solution over a $\mathrm{TiO}_{2} / \mathrm{FTO}$ film. Then, CdS QDS were deposited on a $\mathrm{TiO}_{2} / \mathrm{C}_{60}$-NS film by the SILAR method. The film was immersed in a beaker containing $0.1 \mathrm{M}$ cadmium acetate/methanol for $2 \mathrm{~min}$, rinsed in methanol and dried for $2 \mathrm{~min}$ and then immersed in another beaker containing $0.1 \mathrm{M}$ sodium sulfide/methanol for $2 \mathrm{~min}$, rinsed in methanol and dried for $2 \mathrm{~min}$. Thus, one cycle of deposition was completed. The film was subjected to six more SILAR cycles to obtain a $\mathrm{TiO}_{2} / \mathrm{C}_{60}-\mathrm{NS} / \mathrm{CdS}$ film, which was stored at $45{ }^{\circ} \mathrm{C}$ in an oven in dark. Also, a $\mathrm{TiO}_{2} / \mathrm{C}_{60}-\mathrm{B} / \mathrm{CdS}$ film were fabricated by depositing CdS using 7 cycles of SILAR. Then 2 layers of $\mathrm{ZnS}$ were applied by immersing the photoanode in a $0.1 \mathrm{M}$ zinc acetate/methanol solution for $2 \mathrm{~min}$, followed by a methanol rinse and dried for $2 \mathrm{~min}$ and then in a $0.1 \mathrm{M} \mathrm{Na}_{2} \mathrm{~S} /$ methanol solution for $2 \mathrm{~min}$, rinsed in methanol and dried for $2 \mathrm{~min}$.

\subsection{Counter electrode}

Two electrodes: carbon (C)-cloth and $\mathrm{MoS}_{2} / \mathrm{C}$-cloth were used as CEs. $\mathrm{MoS}_{2} / \mathrm{C}$-cloth was prepared by an in situ hydrothermal method reported by $\mathrm{Yu}$ et $a l^{34}$ In a beaker, $30 \mathrm{mg}$ of $\mathrm{MoO}_{3}$, $45 \mathrm{mg}$ of thioacetamide and $300 \mathrm{mg}$ of ammonium fluoride $\left(\mathrm{NH}_{4} \mathrm{~F}\right)$ were taken and $30 \mathrm{~mL}$ of distilled water was added and it was stirred vigorously for $30 \mathrm{~min}$. The mixture solution was transferred to a $60 \mathrm{~mL}$ Teflon-lined stainless steel autoclave and a C-cloth (area: $6 \mathrm{~cm}^{2}$ ) was kept immersed in it and this assembly was heated in an oven at $200{ }^{\circ} \mathrm{C}$ for $8 \mathrm{~h}$. The autoclave was cooled down to room temperature. The $\mathrm{MoS}_{2} / \mathrm{C}$-cloth was washed in distilled water and ethanol respectively and dried at $60{ }^{\circ} \mathrm{C}$ in a vacuum oven and stored at $45^{\circ} \mathrm{C}$ in an oven in dark, prior to use. The mass loading amount of $\mathrm{MoS}_{2}$ on C-cloth is $1 \mathrm{mg}$.

QDSCs were constructed by assembling a photoanode $\left(\mathrm{TiO}_{2} /\right.$ $\mathrm{C}_{60}-\mathrm{NS} / \mathrm{CdS}$ or $\mathrm{TiO}_{2} / \mathrm{C}_{60}-\mathrm{B} / \mathrm{CdS}$ or $\mathrm{TiO}_{2} / \mathrm{CdS}$ ), a CE (C-cloth or $\mathrm{MoS}_{2} / \mathrm{C}$-cloth) and a polysulfide gel electrolyte (composed of $1 \mathrm{M} \mathrm{Na}_{2} \mathrm{~S}$ and $1 \mathrm{M} \mathrm{S}$ dissolved in deionized water and $5 \%$ fumed silica dispersed therein) in a sandwich configuration. A parafilm spacer was also used to prevent shorting. The cells were illuminated from the rear side for all experiments involving irradiance. The active area of the exposed photoanode was maintained between $0.1 \mathrm{~cm}^{2}$.

\subsection{Characterization techniques}

Raman spectra of pristine $\mathrm{C}_{60}$ and $\mathrm{C}_{60}$-NS were recorded on a Bruker Senterra dispersive Raman microscope spectrometer, having a $532 \mathrm{~nm}$ laser excitation source. X-ray diffraction (XRD) patterns of pristine $\mathrm{C}_{60}, \mathrm{C}_{60}-\mathrm{NS}, \mathrm{MoS}_{2}$ were recorded on a PANalytical, X'PertPRO instrument with a $\mathrm{Cu}-\mathrm{K} \alpha(\lambda=1.5406 \AA)$ radiation. TEM analysis was performed using a Jeol 2100 microscope $(200 \mathrm{kV})$ and samples were directly transferred onto carbon-coated copper grids. Surface morphology of $\mathrm{C}_{60}$-NS was examined under a scanning electron microscope (Zeiss Evo 18 Special Edition). Optical absorption spectra of solutions were measured in absorbance mode and films in diffuse reflectance mode on a UV-Vis spectrophotometer (T90+, PG Instruments). A Horiba Flouromax-4 fluorescence spectrometer was used to measure the fluorescence spectra of electrodes. Emission lifetime was deduced by time-correlated single photon counting (TCSPC) method, using a Horiba Jobin Yvon data station HUB functioning in the TCSPC mode. A nano LED diode was employed as an excitation source having emission pulses at $370 \mathrm{~nm}$ with $1 \mathrm{MHz}$ repetition rate and a pulse duration of 1.3 ns. A Ludox solution (colloidal silica) was used as a prompt to acquire the instrument response function. Current versus potential data of QDSCs were measured using a LOT-Oriel Xe arc lamp, which gave an irradiance of 1 sun $\left(100 \mathrm{~mW} \mathrm{~cm}^{-2}, \mathrm{AM}\right.$ 1.5, coupled with an Autolab PSTAT 302N electrochemical workstation). Light irradiance was measured using a Newport power meter. Cyclic voltammetry, Linear sweep voltammetry plots for the photoactive electrodes and electrochemical impedance spectra (EIS, at an ac amplitude of $20 \mathrm{mV}$ over a frequency range of $1 \mathrm{MHz}$ to $0.1 \mathrm{~Hz}$ ) were recorded on the same workstation. External quantum efficiency (EQE) versus wavelength spectra were recorded by employing a quantum efficiency measurement system, Oriel IQE-200, capable of measurements compliant to ASTM E1021-06 which was equipped with a quartz tungsten halogen lamp as a light source. KPFM (Kelvin probe force microscopy) (Veeco, Multimode 8 with ScanAsyst and Nanoscope 8.10 software) was used for recording topography and surface potential images. A Co/Cr tip with a $\mathrm{Sb}$ doped Silicon cantilever was used as probe with a radius of $10 \mathrm{~nm}$, a spring constant of $0.2 \mathrm{~N} \mathrm{~cm}^{-2}$ and a current sensitivity of $1 \mathrm{nA} \mathrm{V}^{-1}$. Between the tip and sample, a load force of $50 \mathrm{nN}$ was maintained. The sample/FTO glass was affixed on a stainless steel disk with a conducting carbon tape and a silver paste was used for taking contacts. An ac bias of $5 \mathrm{~V}$ was applied between sample and probe and a modulated force was measured between them using a cantilever for recording the surface potential map. Until the oscillation dropped to zero (when applied $V_{\mathrm{dc}}$ equaled to $V_{\mathrm{CPD}}$ i.e., the contact potential difference) KPFM feedback adjusted a dc bias. In the first pass, a topography map was obtained in tapping mode and a surface potential map was measured in the second pass.

\section{Results and discussion}

\subsection{Structural studies}

The transmission electron microscopy (TEM) images of the $\mathrm{C}_{60^{-}}$ NS and the $\mathrm{TiO}_{2} / \mathrm{C}_{60^{-}} \mathrm{NS} / \mathrm{CdS}$ film are shown in Fig. 1 (a-f). $\mathrm{C}_{60^{-}}$ NS show overlapping hexagonal semi-crystalline nanosheets, which are formed at the $\mathrm{CCl}_{4}$-IPA interface (Fig. 1a). Along with the hexagonal nanosheets (NS), particles of other geometric shapes are also observed. This may be due to the aggregation of nanosheets. The edges of a hexagonal sheet are seen in an enlarged view in Fig. 1b. The size of nanosheets lies in the range 

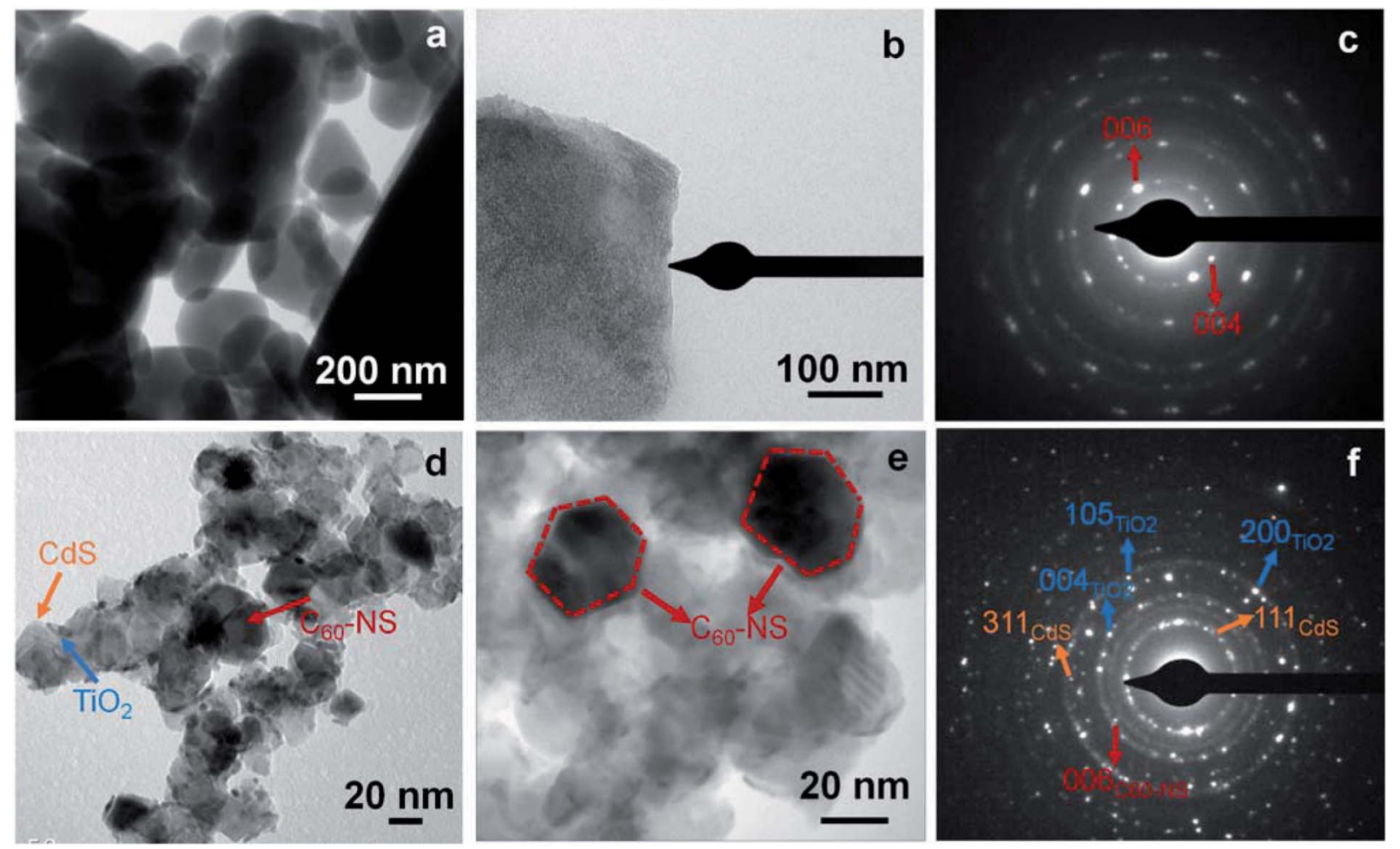

Fig. 1 ( $a$ and b) TEM images of $\mathrm{C}_{60}-\mathrm{NS}$ with (c) the corresponding SAED pattern, ( $d$ and e) TEM images of TiO $/ \mathrm{C}_{60}-\mathrm{NS} / \mathrm{CdS}$ film with (f) the corresponding SAED pattern.

of 200-500 nm. Fig. 1c shows the selected area electron diffraction (SAED) pattern of a $\mathrm{C}_{60}-\mathrm{NS}$, where bright spots are superimposed over concentric diffuse rings. The spots are indexed to the (004) and (006) planes of $\mathrm{C}_{60}$, which correspond to $d=3.18$ and $2.75 \AA$ of the hexagonal structure of fullerene (powder diffraction file (PDF): 470787); this is clearly indicative of the sheet like structure of $\mathrm{C}_{60}$, because $\mathrm{C}_{60}-\mathrm{B}$ has a fcc structure (seen later through diffraction studies), and $\mathrm{C}_{60}-\mathrm{NS}$ are hexagonal. The images of the $\mathrm{TiO}_{2} / \mathrm{C}_{60}-\mathrm{NS} / \mathrm{CdS}$ film (Fig. 1d and e) show $\mathrm{TiO}_{2}$ nanoparticles (seen as large aggregated particles of irregular shapes, $20-50 \mathrm{~nm}$ in dimensions) and CdS QDs (visible as small particles, 5-10 $\mathrm{nm}$ in dimensions) juxtaposed with the $\mathrm{C}_{60}-\mathrm{NS}$, which are seen in the form of hexagonal shapes. From the image in Fig. 1e, the hexagonal shape of the $\mathrm{C}_{60}$-NS in dark contrast is obvious. The SAED pattern (Fig. 1f) shows bright spots that correspond to the lattice planes from the crystal structures of the different components of the photoanode. $\mathrm{TiO}_{2}$ produced spots corresponding to $h k l=(004)$, (200) and (105) planes of the body centered tetragonal structure (PDF: 894921), corresponding to $d=2.37,1.9,1.67 \AA$ A. CdS produces spots due to $h k l=(111)$ and (311) corresponding to $d=3.35$ and $1.77 \AA$ of the face centered cubic (fcc) lattice of CdS (PDF: 652887), and spot due to the (006) plane of hexagonal structured $\mathrm{C}_{60}$ is also observed. These sheets are formed by the liquid-liquid interfacial pressure.

XRD patterns of $\mathrm{C}_{60}-\mathrm{B}, \mathrm{C}_{60}-\mathrm{NS}, \mathrm{MoS}_{2}$ and C-cloth deposited on micro-slide glass substrates are shown in Fig. $2 \mathrm{a}$ and $\mathrm{b}$ and $\mathrm{S} 2 . \dagger$ Bulk fullerene $\left(\mathrm{C}_{60}-\mathrm{B}\right)$ shows peaks at $2 \theta=10.73,17.57$, $20.64,21.57,27.23,27.96,30.7$ and $32.6^{\circ}$ with corresponding $d$ spacings of 8.28, 5.06, 4.3, 4.11, 3.39, 3.2, 2.91 and $2.75 \AA$ that match with (111), (220), (311), (222), (331), (024), (422) and (333) planes respectively of face centered cubic (fcc) lattice of $\mathrm{C}_{60}$ (PDF: 820505) (Fig. 2b). $\mathrm{C}_{60}$-NS shows peaks at $2 \theta=10.8,17.7$, $20.75,21.62,28.06,30.83$ and $32.68^{\circ}$ that correspond to $d$ spacings of 8.19, 5, 4.27, 4.11, 3.18, 2.9 and $2.75 \AA$, aligning with the (002), (110), (112), (004), (114), (300) and (006) planes of a hexagonal primitive structure of $\mathrm{C}_{60}$ (PDF: 470787) (Fig. 2a).

\subsection{Comparison of $\mathrm{C}_{60}-\mathrm{NS}$ and $\mathrm{C}_{60}-\mathrm{B}$}

Fig. 2c shows the Raman spectra of $\mathrm{C}_{60}$-NS and $\mathrm{C}_{60}$ - $\mathrm{B}$ measured in wavenumber range of $50-2500 \mathrm{~cm}^{-1}$ respectively. A peak at $270 \mathrm{~cm}^{-1}$ is due the $\mathrm{H}_{\mathrm{g}}$ (1) squashing mode of $\mathrm{C}_{60}$. Peaks at 1415 and $1575 \mathrm{~cm}^{-1}$ are attributed to the $\mathrm{H}_{\mathrm{g}}(7)$ and $\mathrm{H}_{\mathrm{g}}(8)$ modes of $\mathrm{C}_{60}$. In addition, two strongest Raman lines at 493.8 and $1464 \mathrm{~cm}^{-1}$ are assigned to the two symmetric modes of $\mathrm{A}_{\mathrm{g}}(1)$ and $A_{g}$ (2) corresponding to the double-bond stretching "pentagonal pinch" mode and the "breathing" mode. ${ }^{35}$ The pentagonal pinching mode of $\mathrm{A}_{\mathrm{g}}(1)$ is susceptible to intermolecular interaction. It is noted that in $\mathrm{C}_{60}-\mathrm{NS}$, the $\mathrm{H}_{\mathrm{g}}(1), \mathrm{H}_{\mathrm{g}}(7)$ and $\mathrm{H}_{\mathrm{g}}$ (8) modes are shifted to lower frequencies. It may be attributed to the photo-reaction between the excited $\mathrm{C}_{60}$ and a neighbouring molecule during laser irradiation. ${ }^{36}$ An additional peak was observed at $308.3 \mathrm{~cm}^{-1}$ for $\mathrm{C}_{60}$-NS that was not seen for $\mathrm{C}_{60}-\mathrm{B}$. A peak at $270 \mathrm{~cm}^{-1}$ was split into two peaks showing a high degree of crystallinity present in $\mathrm{C}_{60}$-NS (Fig. $2 \mathrm{~d}$ ).

Fig. 3a, c and b, d show the topography and surface potential maps of $\mathrm{C}_{60}-\mathrm{NS}$ and $\mathrm{C}_{60}-\mathrm{B}$ deposited as thin films on $\mathrm{FTO} /$ glass substrates. During the measurement, a Co/Cr tip of a known 

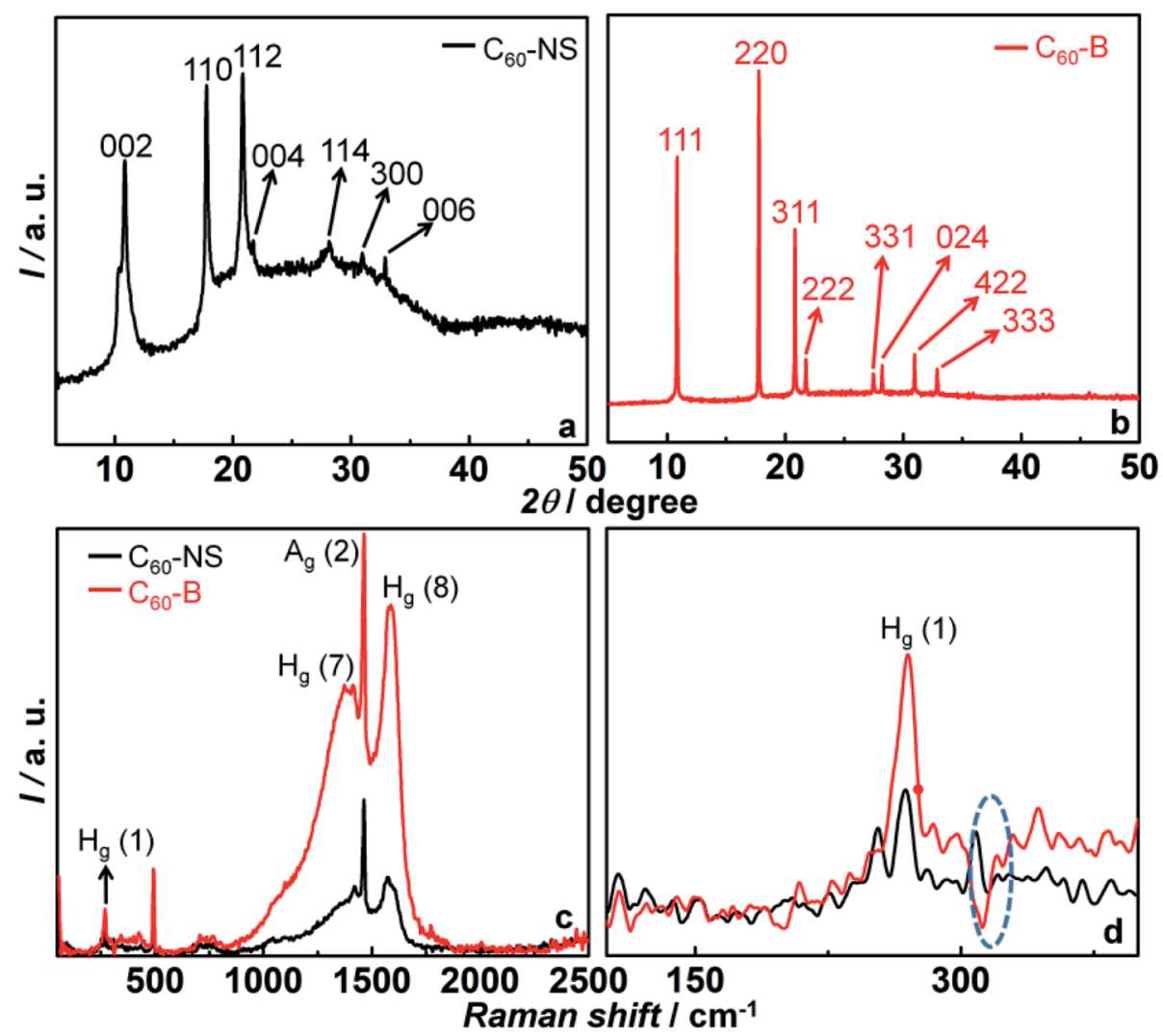

Fig. 2 ( $a$ and b) XRD patterns of $\mathrm{C}_{60}-\mathrm{NS}$ and $\mathrm{C}_{60}-\mathrm{B}$, (c) Raman spectra of $\mathrm{C}_{60}-\mathrm{NS}$ and $\mathrm{C}_{60}-\mathrm{B}$, (d) shows the enlarged view of Raman spectra in $100-400 \mathrm{~cm}^{-1}$ range.

work function $(\varphi)$ was held at a height of $100 \mathrm{~nm}$ from the sample surface. The conducting tip scans the sample surface and electrons are transferred between the two until the Fermi levels (EF) align. The tip maps the topography of the sample in the tapping mode in the first pass and it maps the contact potential difference or surface potential $\left(V_{\mathrm{CPD}}\right)$ as a function of the lateral coordinate in the second pass. The conducting tip was calibrated with highly ordered pyrolytic graphite (HOPG) of a known work function of $4.6 \mathrm{eV}$. For HOPG, the $V_{\mathrm{CPD}}$ was $90 \mathrm{mV}$. Thus, the work function of an unknown sample is determined by the equation.

$$
\varphi_{\text {sample }}=4.6 \mathrm{eV}+V_{\mathrm{CPD}(\mathrm{HOPG})}-V_{\mathrm{CPD}(\text { sample })}
$$

Hence, the work function of $\mathrm{C}_{60}-\mathrm{NS}$ is calculated to be $4.57 \mathrm{eV}$ by using $V_{\mathrm{CPD}}=120 \mathrm{mV}$, whereas the work function of $\mathrm{C}_{60}-\mathrm{B}$ is calculated to be $4.4 \mathrm{eV}$ by using $V_{\mathrm{CPD}}=280 \mathrm{mV}$ respectively. According to literature, the work function of pristine fullerene is $\sim 4.3 \mathrm{eV}$ which is in agreement with the calculated value. ${ }^{16}$ The CB of CdS is poised at $4 \mathrm{eV}$ (Fig. S1b, ESI $\dagger$ ) and therefore, excited electrons upon illumination, can easily cascade into $\mathrm{C}_{60}-\mathrm{B}$ or $\mathrm{C}_{60}-\mathrm{NS}$, via $\mathrm{TiO}_{2}$, which has a $\mathrm{CB}$ at $4.17 \mathrm{eV}$ (Fig. S1a, ESI $\dagger$ ). It must be recalled from the deposition method that $\mathrm{TiO}_{2}$ has a porous matrix and it is in direct contact with $\mathrm{C}_{60}{ }^{-}$ $\mathrm{B}$ or $\mathrm{C}_{60}$-NS. From the $\mathrm{C}_{60}-\mathrm{B}$ or $\mathrm{C}_{60}-\mathrm{NS}$, the electrons are relayed to the current collector (FTO), which has a work function of
$4.7 \mathrm{eV}$ (Fig. 3e). The higher magnitude of energy level gradient between the $\mathrm{CB}$ of $\mathrm{TiO}_{2}$, and $\phi\left(\mathrm{C}_{60}-\mathrm{NS}\right)$ compared to that between the $\mathrm{CB}$ of $\mathrm{CdS}$ and $\phi\left(\mathrm{C}_{60}-\mathrm{B}\right)$ also leads to faster charge injection in the former.

The electrical conductances of $\mathrm{C}_{60}-\mathrm{NS}$ and $\mathrm{C}_{60}-\mathrm{B}$, measured in the linear sweep voltammetry mode, by sandwiching their solutions between two FTO electrodes, and measured at a scan rate of $20 \mathrm{mV} \mathrm{s}^{-1}$ are shown in Fig. 3f. A voltage range of -2 to $+2 \mathrm{~V}$ was applied. I versus $V$ graph for $\mathrm{C}_{60}-\mathrm{B}$ is almost linear in the entire voltage range, however, for $\mathrm{C}_{60}-\mathrm{NS}$, it is linear in the voltage domain of -1 to $+1 \mathrm{~V}$, and beyond these voltages, it steeply increases. The conductances are therefore calculated from the slopes of the linear fits. The conductances of $\mathrm{C}_{60} \mathrm{-NS}$ and $\mathrm{C}_{60}-\mathrm{B}$ are 1.44 and $0.014 \mu \mathrm{S}$ respectively. The greater conductance of the $\mathrm{C}_{60}$-NS, a manifestation of the sheet like structure of fullerene, which allows facile electron transport, is advantageous for improving the PCE of the $\mathrm{TiO}_{2} / \mathrm{CdS}$ cell.

\subsection{Absorbance, fluorescence and lifetime studies}

The absorbance spectra of pristine $\mathrm{TiO}_{2}, \mathrm{CdS}, \mathrm{TiO}_{2} / \mathrm{CdS}, \mathrm{TiO}_{2} /$ $\mathrm{C}_{60}-\mathrm{B} / \mathrm{CdS}$ and $\mathrm{TiO}_{2} / \mathrm{C}_{60}-\mathrm{NS} / \mathrm{CdS}$ are shown in Fig. 4a. Pristine $\mathrm{TiO}_{2}$ and CdS deposited on FTO glass films were measured by diffusion reflectance mode which were converted to absorbance values by Kubelka-Munk function. Absorbance of $\mathrm{C}_{60}-\mathrm{NS}$ and $\mathrm{C}_{60} \mathrm{~B}$ were recorded in liquid media and are displayed in Fig. $4 \mathrm{~b} . \mathrm{TiO}_{2}$ displays a strong absorption in the UV region and 


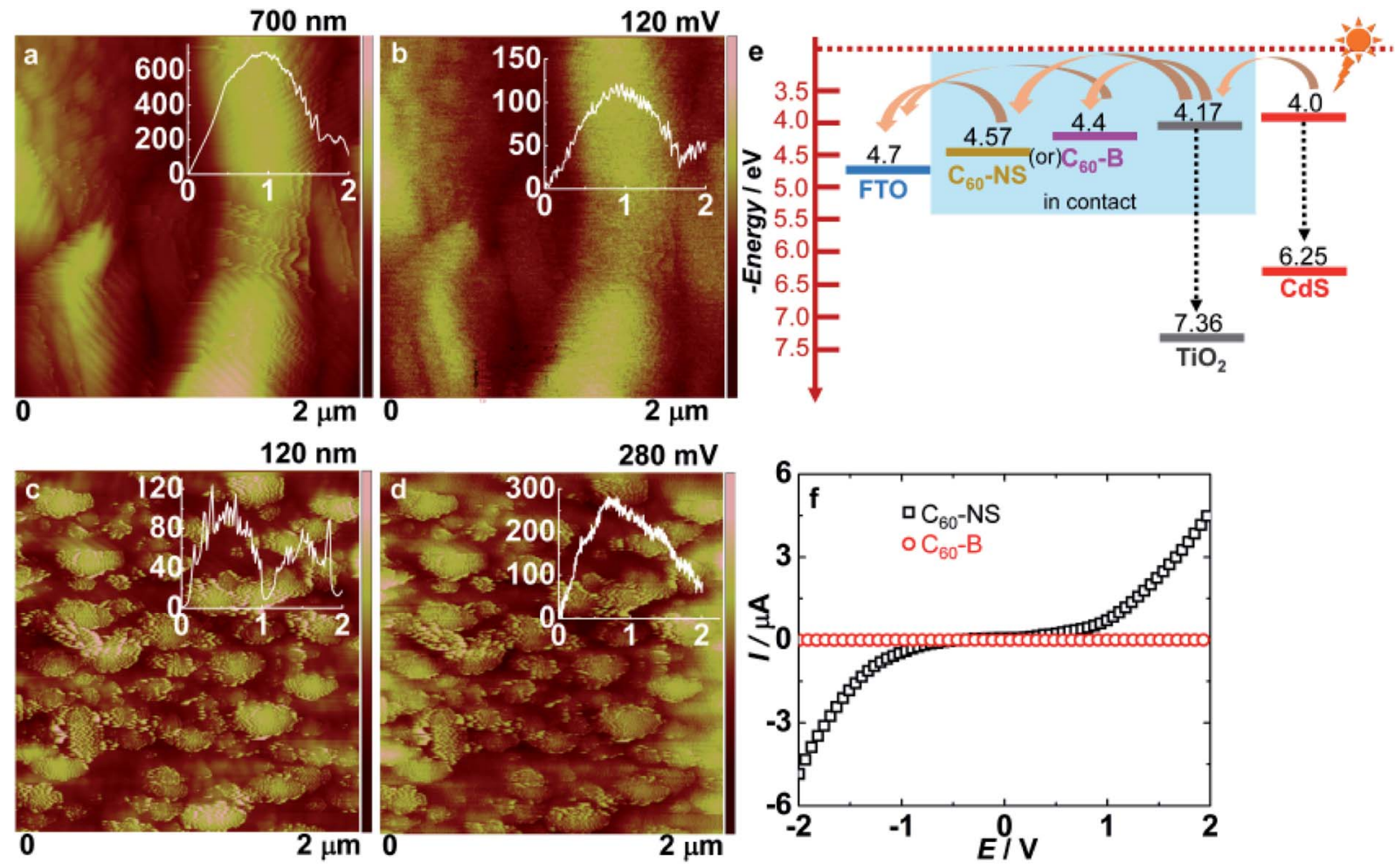

Fig. $3(a, c)$ and $(b, d)$ are topography and surface potential maps of $C_{60}-N S$ and $C_{60}-B$ obtained from KPFM, and (e) energy band diagram of $\mathrm{TiO}_{2} / \mathrm{C}_{60}-\mathrm{NS} / \mathrm{CdS}$ electrode showing the electron transfer modes, (f) linear sweep voltammetry plots of $\mathrm{C}_{60}-\mathrm{NS}$ and $\mathrm{C}_{60}-\mathrm{B}$.

the optical band gap $\left(E_{\mathrm{g}}\right)$ of $\mathrm{TiO}_{2}$ is $3.19 \mathrm{eV}$, obtained by using is calculated to be $2.25 \mathrm{eV}$. $\mathrm{C}_{60}$ - $\mathrm{B}$ shows two intense peaks at 257 the relation $E_{\mathrm{g}}=1240 / \lambda(\mathrm{nm})$. CdS QDs show a broad absorption from 400 to $550 \mathrm{~nm}$ wavelength range, and the optical band gap and $328 \mathrm{~nm}$ in the UV region which are assigned to the allowed electronic transitions between ${ }^{1} \mathrm{~T}_{1 \mathrm{u}}$ (upper excited state) and ${ }^{1} \mathrm{~A}_{\mathrm{g}}$
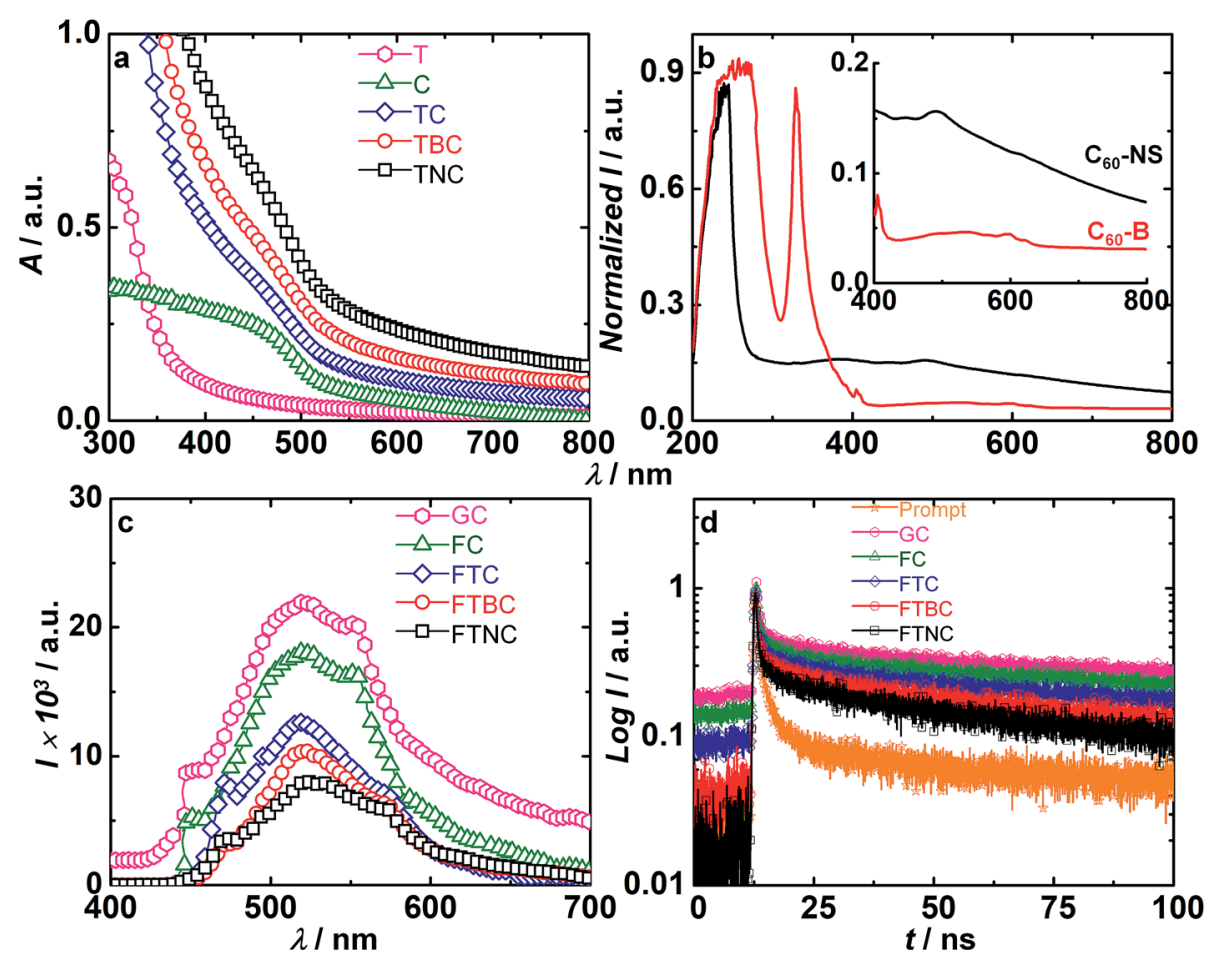

Fig. 4 Absorbance spectra of (a) $\mathrm{TiO}_{2}$ (T), CdS (C), $\mathrm{TiO}_{2} / \mathrm{CdS}(\mathrm{TC}), \mathrm{TiO}_{2} / \mathrm{C}_{60}-\mathrm{B} / \mathrm{CdS}\left(\mathrm{TBC}\right.$ ) and $\mathrm{TiO}_{2} / \mathrm{C}_{60}-\mathrm{NS} / \mathrm{CdS}$ (TNC) films and (b) $\mathrm{C}_{60}-\mathrm{NS}$ and $\mathrm{C}_{60}-\mathrm{B}$; inset of (b) shows an enlarged view in the 400-800 $\mathrm{nm}$ range. (c) Fluorescence spectra and (d) emission decay of different photoanodes deposited on glass (G) and FTO (F) with $\lambda_{\mathrm{ex}}=370 \mathrm{~nm}$ and $\lambda_{\mathrm{em}}=520 \mathrm{~nm}$ (in (d)). 
(ground state). ${ }^{37}$ This is followed a broad flattened band in the visible region spanning 435 to $700 \mathrm{~nm}$, and small humps are observed at 405 and $598 \mathrm{~nm}$ respectively. These peaks are due to $\mathrm{A}_{\mathrm{o}}+\mathrm{h}_{\mathrm{g}}$ and forbidden interleaved vibronic bands of ${ }^{1} \mathrm{~T}_{2 \mathrm{~g}}-{ }^{1} \mathrm{~A}_{\mathrm{g}}$ and ${ }^{1} \mathrm{~T}_{1 \mathrm{~g}}-{ }^{1} \mathrm{~A}_{\mathrm{g}}$. The latter are electronic transitions with a vibrational structure. ${ }^{37} \mathrm{C}_{60}$-NS shows a single strong peak at $241 \mathrm{~nm}$, and weak broad peaks are observed at 381, 491 and $613 \mathrm{~nm}$. The $\mathrm{C}_{60}$-NS showed a broad band from 380 to $800 \mathrm{~nm}$. The peaks profile is different for the NS, compared to bulk fullerene, due to structural differences, which were also evidenced from the Raman spectral data. The $241 \mathrm{~nm}$ peak is due to ${ }^{1} \mathrm{~T}_{1 \mathrm{u}}-{ }^{1} \mathrm{~A}_{\mathrm{g}}$ transitions. The peaks in the visible region area are again due to the forbidden vibronic transitions.

$\mathrm{C}_{60}$-NS can also therefore contribute as photosensitizers and improve the light harvesting capability of the QDSC. The $\mathrm{TiO}_{2} /$ CdS film shows a broad absorption band in a visible region ranging from 400 to $550 \mathrm{~nm}$. When $\mathrm{C}_{60}$-B deposited between $\mathrm{TiO}_{2}$ and CdS, there is an increase in the overall absorption intensity. Further, by incorporation of $\mathrm{C}_{60}$-NS between $\mathrm{TiO}_{2}$ and $\mathrm{CdS}$, the absorbance is further increased compared to $\mathrm{TiO}_{2} / \mathrm{C}_{60^{-}}$ $\mathrm{B} / \mathrm{CdS}$, indicating that $\mathrm{C}_{60}-\mathrm{NS}$ are more effective than $\mathrm{C}_{60}-\mathrm{B}$ in capturing visible photons.

Fig. 4c shows the emission spectra of 5 films, i.e., glass/CdS, FTO/CdS, $\mathrm{TiO}_{2} / \mathrm{CdS}, \mathrm{TiO}_{2} / \mathrm{C}_{60}-\mathrm{B} / \mathrm{CdS}$ and $\mathrm{TiO}_{2} / \mathrm{C}_{60}-\mathrm{NS} / \mathrm{CdS}$ films measured at an excitation wavelength of $370 \mathrm{~nm}$. Glass/CdS reveals a broad emission peak at $520 \mathrm{~nm}$ caused by a radiative band edge recombination and emission from the transitions between the mid-gap states. Compared to this, the emission intensity of FTO/CdS film drops by $18 \%$ due to electron transfer from CdS to FTO. It drops by $42 \%$ for $\mathrm{TiO}_{2} / \mathrm{CdS}$ with respect to glass/CdS, due electron transfer from the conduction band (CB) of CdS to the $\mathrm{CB}$ of $\mathrm{TiO}_{2}$. Upon the inclusion of $\mathrm{C}_{60}-\mathrm{B}$ and $\mathrm{C}_{60}-\mathrm{NS}$ in the $\mathrm{TiO}_{2} / \mathrm{CdS}$ films, the emission intensity of CdS film is quenched by $52 \%$ and $64 \%$ respectively with respect to Glass/ CdS. $\mathrm{C}_{60}-\mathrm{NS}$ is more efficient at accepting photo-excited electrons from the $\mathrm{CB}$ of CdS than $\mathrm{C}_{60}-\mathrm{B}$.

To study the mechanism of excited electron deactivation from CdS, time-resolved emission decay plots were recorded and are shown in Fig. $4 \mathrm{~d}$. The decay data were fitted to a biexponential function for all the films.

$$
I=B_{1} \exp \left(-t / \tau_{1}\right)+B_{2} \exp \left(-t / \tau_{2}\right)
$$

Thus the electron life time was determined by the equation,

$$
\langle\tau\rangle=\Sigma B_{i} \tau_{i}^{2} / \Sigma B_{i} \tau_{i}
$$

where, $B_{1}$ and $B_{2}$ are the amplitude coefficients, $\tau_{1}$ and $\tau_{2}$ are the electron lifetime decay constants, and $\tau$ is the average electron lifetime.

The average lifetime of glass/CdS film is $17 \mathrm{~ns}$ (Table $\mathrm{S} 1 \dagger) . \tau_{1}$ corresponds to quenching via inter-particle charge transfer, and $\tau_{2}$ corresponds to the time for which the electron resides in the excited state prior to recombination with the holes in the valence band (VB) or trapping in the defect states. The $\tau_{\text {avg }}$ of the FTO/CdS and $\mathrm{TiO}_{2} / \mathrm{CdS}$ films are reduced to 12.98 and further to $6.76 \mathrm{~ns}$. In the FTO/CdS film, $\tau_{1}$ is due to band edge recombination in CdS and $\tau_{2}$ is due to electron injection from CdS to FTO. In the $\mathrm{TiO}_{2} / \mathrm{CdS}$ film, $\tau_{1}$ is due to electron injection from CdS to $\mathrm{TiO}_{2}$ and $\tau_{2}$ is due to the band-gap electron-hole pairing. When $\mathrm{C}_{60}-\mathrm{B}$ and $\mathrm{C}_{60}-\mathrm{NS}$ are included between $\mathrm{TiO}_{2}$ and $\mathrm{CdS}$, the depopulation pathway for electron transfer becomes facile, for they are well-established electron acceptors. The lowest lifetime achieved with $\mathrm{C}_{60}$-NS shows that a good contact exists between $\mathrm{CdS}$ and $\mathrm{C}_{60}-\mathrm{NS}$ and the NS are more conducive for accepting electrons from the $\mathrm{CB}$ of $\mathrm{CdS}$ than $\mathrm{C}_{60}-\mathrm{B}$ is. Therefore in $\mathrm{TiO}_{2} / \mathrm{C}_{60}-\mathrm{B} / \mathrm{CdS}$ and $\mathrm{TiO}_{2} / \mathrm{C}_{60}-\mathrm{NS} / \mathrm{CdS}, \tau_{1}$ corresponds to electron transfer from CdS to $\mathrm{TiO}_{2} / \mathrm{C}_{60}-\mathrm{NS}$ or $\mathrm{TiO}_{2} /$ $\mathrm{C}_{60}-\mathrm{B}$, and $\tau_{2}$ corresponds to band-edge recombination. The rate constants for electron transfer from the $\mathrm{CB}$ of $\mathrm{CdS}$ to the $\mathrm{CB}$ of $\mathrm{C}_{60}-\mathrm{B}$ or $\mathrm{C}_{60}$-NS were calculated by using the following equations.

$$
\begin{gathered}
k_{\mathrm{et}}=1 /\langle\tau\rangle\left(\mathrm{TiO}_{2} / \mathrm{C}_{60}-\mathrm{B} / \mathrm{CdS}\right)-1 /\langle\tau\rangle\left(\mathrm{TiO}_{2} / \mathrm{CdS}\right) \\
k_{\mathrm{et}}=1 /\langle\tau\rangle\left(\mathrm{TiO}_{2} / \mathrm{C}_{60}-\mathrm{NS} / \mathrm{CdS}\right)-1 /\langle\tau\rangle\left(\mathrm{TiO}_{2} / \mathrm{CdS}\right)
\end{gathered}
$$

Hence the rate constant for the electron transfer for $\mathrm{C}_{60}-\mathrm{B}$ and $\mathrm{C}_{60}$-NS are determined to be $0.575 \times 10^{9} \mathrm{~s}^{-1}$ and $1.4 \times 10^{9}$ $\mathrm{s}^{-1}$ respectively. This implied the faster electron transfer from the $\mathrm{CB}$ of $\mathrm{CdS}$ to $\mathrm{C}_{60}-\mathrm{NS}$ and this facilitated better charge extraction from $\mathrm{C}_{60}-\mathrm{NS}$ than from $\mathrm{C}_{60}-\mathrm{B}$.

\subsection{Counter electrode characterization}

Raman spectra of C-cloth and $\mathrm{MoS}_{2} / \mathrm{C}$-cloth are displayed in Fig. S2a. $\dagger$ The D- and G-bands are observed for both samples, which originates from carbon of the C-cloth. The D-band is due to defects owing to the presence of oxygen containing groups. The G-band is due to graphitic carbon, the $\mathrm{sp}^{2}$ hybridized carbon. The $I_{\mathrm{D}} / I_{\mathrm{G}}$ ratio for C-cloth is 1.16 and for $\mathrm{MoS}_{2} / \mathrm{C}$-cloth, it is 1.025 (Table S2, ESI $\dagger$ ). Perhaps $\mathrm{MoS}_{2}$ passivates some of the surface defects on C-cloth. $\mathrm{MoS}_{2}$ also shows two peaks at 367 and $407 \mathrm{~cm}^{-1}$ corresponding to the $\mathrm{E}_{2 \mathrm{~g}}{ }^{1}$ mode that arises from the in-plane vibration and the $\mathrm{A}_{\mathrm{g}}{ }^{1}$ from the out-of-plane vibrational mode of Mo-S bonds. ${ }^{38}$ Fig. S2b $\uparrow$ shows the XRD pattern of $\mathrm{MoS}_{2}$ with peaks at $2 \theta=14.1,33.4$ and $58.5^{\circ}$ that correspond to $d=6.27,2.68$ and $1.58 \AA$ which agree with the (002), (101), and (110) planes of a primitive lattice of a hexagonal structure (PDF: 371492). C-cloth shows a broad peaks at $2 \theta=24.5$ and $44.2^{\circ}$ corresponding to $d=3.63$ and $2.05 \AA$, matching with the (002) and (101) planes of graphitic carbon (PDF: 751621).

Fig. $5 \mathrm{a}$ and $\mathrm{b}$ show the topography and surface potential maps of $\mathrm{MoS}_{2}$. Nano-sized particles of $\mathrm{MoS}_{2}$ are observed. They are discrete in some regions. The corresponding surface potential map shows the particles to be characterized by relatively higher potentials. The bright contrast corresponds to high potentials and the dark regions correspond to lower potentials. The work function of $\mathrm{MoS}_{2}$ is calculated using eqn (1). It was determined to be $4.6 \mathrm{eV}$ by using a $V_{\mathrm{CPD}}$ of $90 \mathrm{mV}$. This work function is suitable for electron transfer from C-cloth to $\mathrm{MoS}_{2}$, and then subsequently to the reduced electrolyte species during solar cell operation. Fig. 5c and d show the SEM images of Ccloth and $\mathrm{MoS}_{2} / \mathrm{C}$-cloth. Pristine C-cloth displays a woven matlike structure composed of intertwined fibers made up of 
carbon, which are smooth and continuous. $\mathrm{MoS}_{2} / \mathrm{C}$-cloth shows $\mathrm{MoS}_{2}$ particles of no specific shape uniformly coated over the Ccloth, which is conducive for fast electron injection from $\mathrm{C}$ cloth to $\mathrm{MoS}_{2}$, when its' used as a CE in a QDSC.

To further confirm the superior efficacy of the $\mathrm{MoS}_{2} / \mathrm{C}$-cloth compared to C-cloth at transferring electrons to the electrolyte during cell operation, electrochemical impedance spectroscopy studies were performed. Symmetric cells of $\mathrm{MoS}_{2} / \mathrm{C}$-cloth-polysulfide- $\mathrm{MoS}_{2} / \mathrm{C}$-cloth and C-cloth-polysulfide-C-cloth configurations were constructed, and the corresponding Nyquist plots, recorded under a dc bias of $0 \mathrm{~V}$, over a frequency range of $0.1 \mathrm{~Hz}$ to $1 \mathrm{MHz}$ are compared in Fig. $5 \mathrm{e}$. Here, $R_{\mathrm{S}}$, the high frequency real-axis intercept, represents the polysulfide and contact resistance, and $R_{\mathrm{CT}}$ is a measure of the charge transfer resistance at the electrode/electrolyte interface and is equal to the diameter of the high to intermediate frequency skewed semicircle. The span of the second (low frequency) semicircle is a measure of the resistance to charge transfer at the grain boundaries $\left(R_{\mathrm{gb}}\right)$, which can be described as: C-cloth/MoS $\mathrm{M}_{2}$ or $\mathrm{MoS}_{2} / \mathrm{MoS}_{2}$ or C-cloth/C-cloth boundaries, across the crosssection of the active material. Table S3 (ESI $\dagger$ ) provides the impedance parameters. $R_{\mathrm{CT}}$ and $R_{\mathrm{gb}}$ are lower and higher in magnitudes for the $\mathrm{MoS}_{2} / \mathrm{C}$-cloth cell relative to the $\mathrm{C}$-cloth cell suggestive of enhanced capability of $\mathrm{MoS}_{2} / \mathrm{C}$-cloth to transfer electrons at the electrode/electrolyte interface, and also to propagate electrons across the active electrode, when used as a CE in a QDSC.

To compare the electrocatalytic activity of the two CEs for the reduction of the polysulfide species, linear sweep voltammetry was performed in a three electrode system containing C-cloth or $\mathrm{MoS}_{2} / \mathrm{C}$-cloth as the working electrode, a Pt rod as the CE and $\mathrm{Ag} / \mathrm{AgCl} / \mathrm{KCl}$ as the reference electrode in a solution of $1 \mathrm{M} \mathrm{S}$ and $1 \mathrm{M} \mathrm{Na}_{2} \mathrm{~S}$ with $0.2 \mathrm{M} \mathrm{KCl}$ as the supporting electrolyte (Fig. 5f). Both electrodes showed a reduction peak at $-0.59 \mathrm{~V}$, corresponding to the reduction of $\mathrm{S}_{n}{ }^{2-}$ to $n \mathrm{~S}^{2-}$. $\mathrm{MoS}_{2} / \mathrm{C}$-cloth exhibited a high current density for polysulfide reduction compared to C-cloth, which is indicative of a superior electrocatalytic activity in the former.

\section{5 $\mathrm{MoS}_{2}$ as a supercapacitor electrode}

In addition to the employing the $\mathrm{MoS}_{2} / \mathrm{C}$-cloth electrode as a $\mathrm{CE}$ in QDSCs, the energy storage properties of this electrode were studied. To determine the supercapacitance performance of $\mathrm{MoS}_{2} / \mathrm{C}$-cloth, cyclic voltammetry and galvanostatic chargedischarge measurements were recorded for symmetric cells based on the same and these are shown in Fig. 6. A sandwich type symmetric cell with two $\mathrm{MoS}_{2} / \mathrm{C}$-cloth electrodes facing each other and separated by a separator soaked with $1 \mathrm{M} \mathrm{KCl}$ electrolyte was used. Cyclic voltammograms of the $\mathrm{MoS}_{2} / \mathrm{C}$-cloth
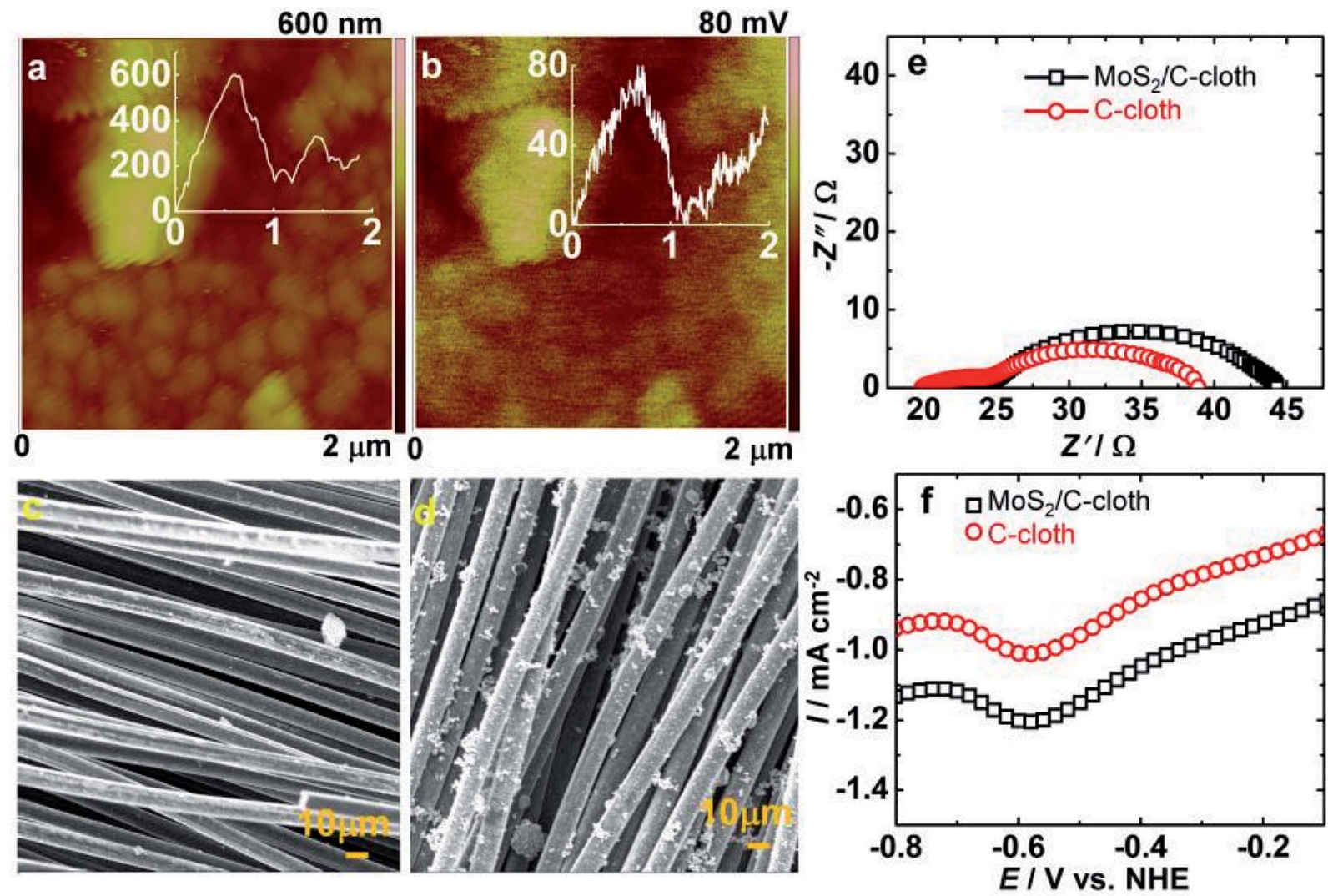

Fig. 5 ( $a$ and b) Topography and surface potential images of $\mathrm{MoS}_{2}$ and (c and d) SEM images of C-cloth and MoS $/ \mathrm{C}$-cloth, (e) Nyquist plots of CE cells in symmetric cell configurations and (f) linear sweep voltammograms of the two CEs (as working electrodes) in a $1 \mathrm{M} \mathrm{Na} 2 \mathrm{~S}, 1 \mathrm{M} \mathrm{S}$ solution in ultrapure water containing $0.2 \mathrm{M} \mathrm{KCl}$ as supporting electrolyte. A Pt rod was used as the auxiliary electrode, and an $\mathrm{Ag} / \mathrm{AgCl} / \mathrm{KCl}$ was used as a reference electrode. 

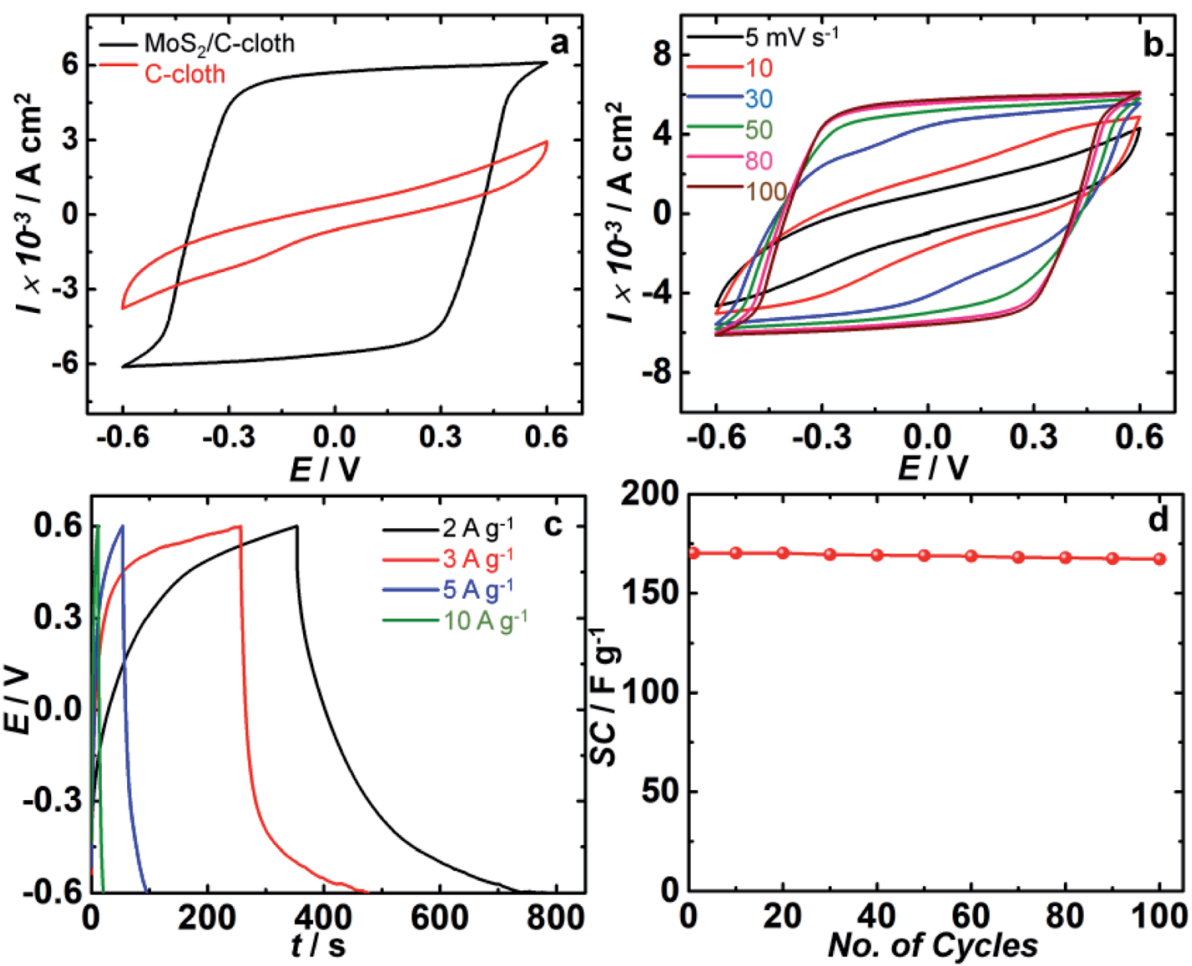

Fig. 6 Cyclic voltammograms of $\mathrm{MoS}_{2} / \mathrm{C}$-cloth and pristine C-cloth based symmetric cells recorded at $100 \mathrm{mV} \mathrm{s}{ }^{-1} \mathrm{scan}$ rate. (b) Cyclic voltammograms of $\mathrm{MoS}_{2} / \mathrm{C}$-cloth symmetric cell at scan rates of 5,10,30,50,80,100 $\mathrm{mV} \mathrm{s}^{-1}$. (c) Galvanostatic charge-discharge characteristics of $\mathrm{MoS}_{2} / \mathrm{C}$-cloth electrodes at different current densities $\left(2,3,5,10 \mathrm{~A} \mathrm{~g}^{-1}\right.$ ). (d) Cycling stability performance of the MoS $/ 2$-cloth based symmetric cell.

based symmetric cell were recorded at different scan rates of 5 , $10,30,50,80$ and $100 \mathrm{mV} \mathrm{s}^{-1}$ in voltage ranges from -0.6 to $0.6 \mathrm{~V}$ and the comparative $\mathrm{CV}$ scans of C-cloth and $\mathrm{MoS}_{2} / \mathrm{C}$-cloth at $100 \mathrm{mV} \mathrm{s}^{-1}$ scan rate are shown in Fig. $6 \mathrm{a}$ and b. The chargedischarge characteristics at different current densities of 2, 3, 5 and $10 \mathrm{~A} \mathrm{~g}^{-1}$ are shown in Fig. 6c. The cycling stability performance of the $\mathrm{MoS}_{2} / \mathrm{C}$-cloth symmetric cell at $5 \mathrm{~A} \mathrm{~g}^{-1}$ was recorded over a similar voltage window (Fig. 6d). The specific capacitance (SC) in $\mathrm{F} \mathrm{g}^{-1}$, energy density $(E)$ in $\mathrm{W} \mathrm{h} \mathrm{kg}^{-1}$ and power density $(P)$ in $\mathrm{W} \mathrm{kg}^{-1}$ can be calculated from the following equations, obtained from the charge-discharge analysis shown in Table 1.

$$
\mathrm{SC}\left(\mathrm{F} \mathrm{g}^{-1}\right)=I \times \Delta t / \Delta V
$$

In (6), $I$ is current density in $\mathrm{A} \mathrm{g}^{-1}, \Delta t$ is discharge time in $s$ and $\Delta V$ is operating voltage window in $V$ respectively.

$$
\begin{gathered}
E\left(\mathrm{~W} \mathrm{~h} \mathrm{~kg}^{-1}\right)=0.5 \mathrm{SC} \times \Delta V^{2} \times 1000 / 3600 \\
P\left(\mathrm{~W} \mathrm{~kg}^{-1}\right)=3600 \times E / \Delta t
\end{gathered}
$$

The CV plot of C-cloth and $\mathrm{MoS}_{2} / \mathrm{C}$-cloth are compared at a scan rate of $100 \mathrm{mV} \mathrm{s}^{-1}$ in the voltage window of -0.6 to $0.6 \mathrm{~V}$. C-cloth shows a low enclosed area, an elliptical CV curve, while $\mathrm{MoS}_{2} / \mathrm{C}$-cloth shows a rectangular CV curve with no redox peaks indicating a good electrochemical double layer capacitive behavior of $\mathrm{MoS}_{2}$. This implies a higher storage capacity for $\mathrm{MoS}_{2} / \mathrm{C}$-cloth compared to sole C-cloth. Here C-cloth acts as a current collector, and the corresponding cell of $\mathrm{C}$-cloth/ $\mathrm{KCl} / \mathrm{C}$ cloth behaves largely like an electrolytic capacitor. The pseudocapacitive nature of $\mathrm{MoS}_{2}$ reaches a high performance by storing charge and releasing charge through oxidation and reduction. The in situ growth of $\mathrm{MoS}_{2}$ on C-cloth allows for

\begin{tabular}{|c|c|c|c|c|}
\hline 2 & 387 & 645 & 129 & 1.2 \\
\hline 5 & 41 & 170.8 & 34.1 & 3 \\
\hline 10 & 9.3 & 77.5 & 15.5 & 6 \\
\hline
\end{tabular}
a large the number of available electroactive sites.

Table 1 Electrochemical supercapacitive performances of $\mathrm{MoS}_{2} / \mathrm{C}$-cloth at different current densities 
The mechanism of the non-faradaic reaction is due to the formation of an electrical double layer of ions and electrons at the electrode/electrolyte interface by the adsorption of ions at the $\mathrm{MoS}_{2}$ surface.

$$
\mathrm{MoS}_{2}+\mathrm{K}^{+}+\mathrm{e}^{-} \leftrightarrow \mathrm{MoS}_{2}-\mathrm{K}^{+}
$$

Also, faradaic charge transfer occurs due to the diffusion of $\mathrm{K}^{+}$into the interlayer of $\mathrm{MoS}_{2}$.

$$
\mathrm{MoS}_{2}+\mathrm{K}^{+}+\mathrm{e}^{-} \leftrightarrow \mathrm{MoS}-\mathrm{SK}^{+}
$$

Fig. $6 \mathrm{~b}$ displays the $\mathrm{CV}$ curve of $\mathrm{MoS}_{2} / \mathrm{C}$-cloth at various scan rates. It follows a rectangular type $\mathrm{CV}$ at higher scan rates and at lower scan rates it remained as elliptical. The anodic and cathodic current densities and the area under the curve increase as a function of scan rate. For instance, the anodic current density maxima increased from 4.2 to $6.1 \mathrm{~mA} \mathrm{~cm}^{-2}$ when the scan rate is raised from 5 to $100 \mathrm{mV} \mathrm{s}^{-1}$.

Galvanostatic charge-discharge of $\mathrm{MoS}_{2} / \mathrm{C}$-cloth based symmetric cells at four different current densities (2, 3, 5, $10 \mathrm{~A} \mathrm{~g}^{-1}$ ) over a voltage window of -0.6 to $0.6 \mathrm{~V}$ are shown in Fig. 6c. It is observed that at a current density of $2 \mathrm{~A} \mathrm{~g}^{-1}$, the specific capacitance is found to be $645 \mathrm{~F} \mathrm{~g}^{-1}$ which is the highest capacitance value among four current densities. Moreover, with the increasing current densities, specific capacitance of $\mathrm{MoS}_{2} / \mathrm{C}$-cloth decreased due to insufficient time for the ions to diffuse through the bulk of the $3 \mathrm{D}$ electrode. The energy density and power density at $2 \mathrm{~A} \mathrm{~g}^{-1}$ were calculated to be $129 \mathrm{~W} \mathrm{~h} \mathrm{~kg}^{-1}$ and $1.2 \mathrm{~kW} \mathrm{~kg}^{-1}$. At current densities of 3,5 and $10 \mathrm{~A} \mathrm{~g}^{-1}$, the specific capacitances of the $\mathrm{MoS}_{2} / \mathrm{C}$-cloth based cell were found to be $415,170.8$ and $77.5 \mathrm{~F} \mathrm{~g}^{-1}$ respectively. Fig. $6 \mathrm{~d}$ shows the cycling stability of $\mathrm{MoS}_{2} / \mathrm{C}$-cloth cell, and the capacitance decreased by $1.8 \%$ after 100 cycles.

\subsection{Solar cell performances}

QDSCs with the following photoanodes: $\mathrm{TiO}_{2} / \mathrm{C}_{60}-\mathrm{NS} / \mathrm{CdS}, \mathrm{TiO}_{2} /$ $\mathrm{C}_{60}-\mathrm{B} / \mathrm{CdS}$ and $\mathrm{TiO}_{2} / \mathrm{CdS}$ and the two CEs: $\mathrm{MoS}_{2} / \mathrm{C}$-cloth and Ccloth are shown in Fig. 7a and b. With a given photoanode, the current density $(J)$ versus voltage $(V)$ response is collected from two cells. The $J-V$ characteristics were obtained under 1 sun irradiance (AM 1.5 spectrum, $100 \mathrm{~mW} \mathrm{~cm}^{-2}$ ). Among all the cell, the $\mathrm{TiO}_{2} / \mathrm{CdS}$ cell shows the lowest PCE of about $3 \%$ and an open circuit voltage $\left(V_{\text {OC }}\right)$ of $661 \mathrm{mV}$ with C-cloth as a CE. The $\mathrm{TiO}_{2} / \mathrm{CdS}$ anode, when coupled with a $\mathrm{MoS}_{2} / \mathrm{C}$-cloth, yielded a PCE of $3.7 \%$ and a $V_{O C}$ of $685 \mathrm{mV}$. By the inclusion of $\mathrm{C}_{60}-\mathrm{B}$ between $\mathrm{TiO}_{2} / \mathrm{CdS}$, the short circuit current density $\left(J_{\mathrm{SC}}\right)$ increases from 11.3 to $14.2 \mathrm{~mA} \mathrm{~cm}{ }^{-2}$. $\mathrm{C}_{60}$ alone may not be effective, but when used in combination with a photosensitizer, it transports electrons rapidly. With $\mathrm{MoS}_{2} / \mathrm{C}$-cloth as the $\mathrm{CE}$, the $\mathrm{C}_{60}$-B based cell shows a higher efficiency of about $4.9 \%$ and a higher $V_{\mathrm{OC}}$ of $724 \mathrm{mV}$ compared to the performance with pristine C-cloth as CE. In the latter, a PCE of $4.4 \%$ and a $V_{\text {OC }}$ of $650.8 \mathrm{mV}$ is achieved. Higher $V_{\mathrm{OC}}$ is attributed to the higher catalytic activity of $\mathrm{MoS}_{2}$, which drives the electrons to the polysulfide redox couple. The fill factor (FF) is high, and it is 0.47 with this $\mathrm{CE}$. The highest PCE is 5.6\%, achieved for the $\mathrm{TiO}_{2} / \mathrm{C}_{60}-\mathrm{NS} / \mathrm{CdS}$ cell with a $\mathrm{MoS}_{2} / \mathrm{C}$-cloth $\mathrm{CE}$. By the inclusion of $\mathrm{C}_{60}-\mathrm{NS}$ in $\mathrm{TiO}_{2} / \mathrm{CdS}$ cell, a noticeable increment in $J_{\mathrm{SC}}$ is observed, as it is now $16.2 \mathrm{~mA} \mathrm{~cm}^{-2}$. The higher $J_{\mathrm{SC}}$ is indicative of the high electrical conductivity of $\mathrm{C}_{60}$-NS. For this cell, the
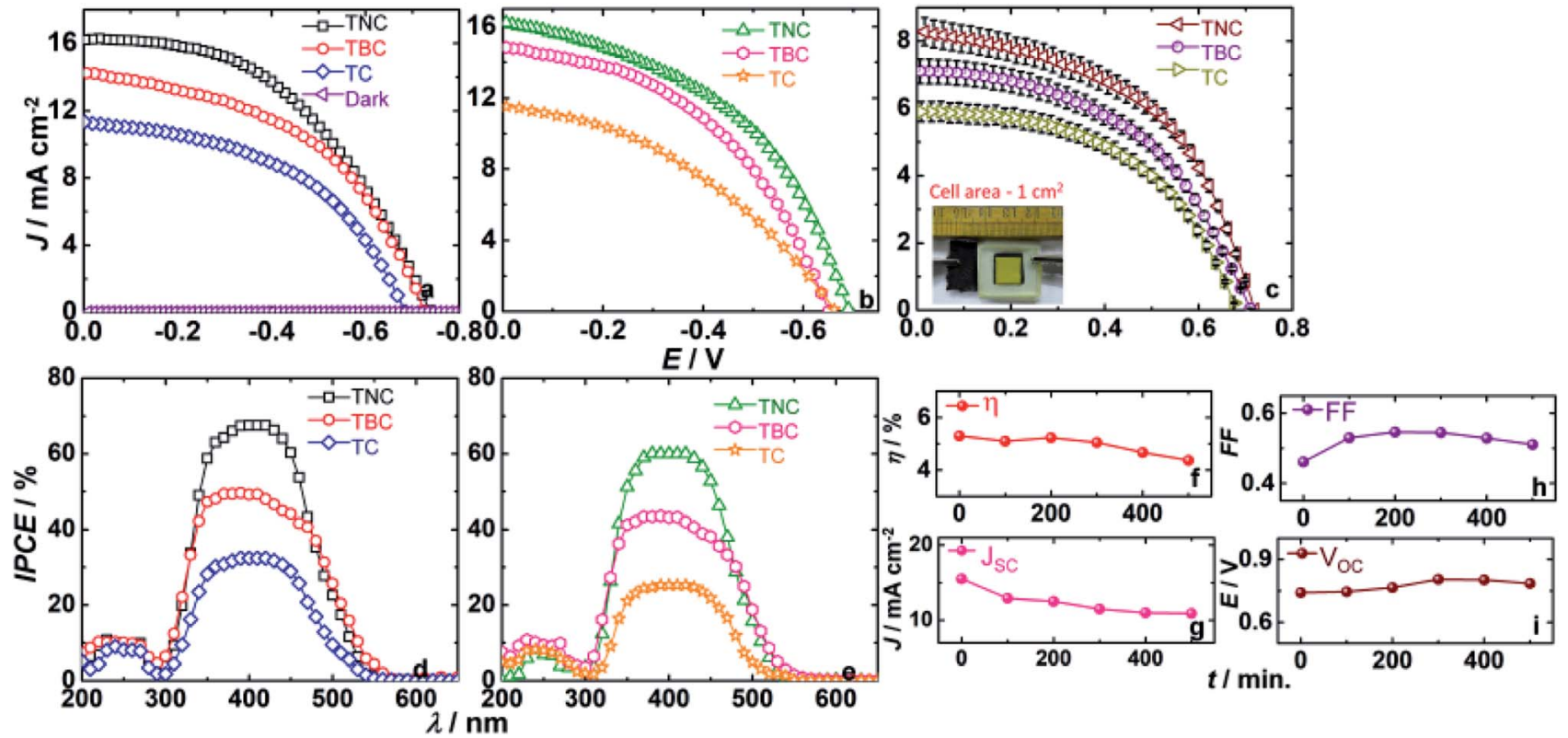

Fig. $7 \mathrm{~J}-V$ characteristics of QDSCs with different photoanodes $\mathrm{TiO}_{2} / \mathrm{CdS}(\mathrm{TC}), \mathrm{TiO}_{2} / \mathrm{C}_{60}-\mathrm{B} / \mathrm{CdS}(\mathrm{TBC})$ and $\mathrm{TiO}_{2} / \mathrm{C}_{60}-\mathrm{N} / \mathrm{CdS}(\mathrm{TNC})$ under 1 sun illumination and in dark and with two CEs: (a) $\mathrm{MoS}_{2} / \mathrm{C}$-cloth and (b) C-cloth, (c) J-V curves of QDSCs with large area photoanodes (area $1 \mathrm{~cm}^{2}$ ) under 1 sun illumination with $\mathrm{MoS}_{2} / \mathrm{C}$-cloth $\mathrm{CEs}$ and a polysulfide gel electrolyte (inset is the photograph of the complete device in sandwich configuration) and IPCE versus wavelength of QDSCs with different photoanodes with two CEs: (d) MoS $/$ C-cloth and (e) C-cloth, temporal evolution of photovoltaic parameters (f) PCE; (g) $\mathrm{J}_{\mathrm{SC}}$; (h) FF and (i) $V_{\mathrm{OC}}$, of a QDSC with a $\mathrm{TiO}_{2} / \mathrm{C}_{60}-\mathrm{NS} / \mathrm{CdS}$ photoanode, and a MoS $/ \mathrm{C}$-cloth as the CE. 
$V_{\mathrm{OC}}$ is $736.2 \mathrm{mV}$ and $\mathrm{FF}$ is 0.47 greater than that obtained for an analogous cell having C-cloth as the CE, which delivers a PCE of $5.1 \%$. The $V_{\text {OC }}$ and $\mathrm{FF}$ are $689.8 \mathrm{mV}$ and $0.45 \%$ respectively. This difference clearly highlights the role of $\mathrm{MoS}_{2}$ in improving the electrocatalytic activity of C-cloth. The solar cell parameters are given in Table 2.

In addition to this, cells with photoanodes with large area (1 $\mathrm{cm}^{2}$ ) are assembled using $\mathrm{MoS}_{2} / \mathrm{C}$-cloth CEs and a polysulfide gel electrolyte for $J-V$ measurements shown in Fig. 7c. The lowest PCE of $2 \%$ is delivered by the $\mathrm{TiO}_{2} / \mathrm{CdS}$ film with a $J_{\mathrm{SC}}$ of $5.9 \mathrm{~mA} \mathrm{~cm}^{-2}$ and $V_{\mathrm{OC}}$ of $675 \mathrm{mV}$ respectively. For the $\mathrm{TiO}_{2} / \mathrm{C}_{60}-\mathrm{B} /$ CdS cell, the photocurrent is enhanced to $7.2 \mathrm{~mA} \mathrm{~cm} \mathrm{~cm}^{-2}$ and $V_{\mathrm{OC}}$ gradually increased to $692.3 \mathrm{mV}$ exhibiting a high PCE of $2.5 \%$. The fill factor is relatively higher than the previous cell. By the inclusion of $\mathrm{C}_{60}$-NS, charge transfer is easier than $\mathrm{C}_{60}-\mathrm{B}$ due to the high surface area and high conductivity of $\mathrm{C}_{60}-\mathrm{NS}$. It helps in increasing photocurrent to $8 \mathrm{~mA} \mathrm{~cm}^{-2}$ with a $V_{\mathrm{OC}}$ of $717.3 \mathrm{mV}$ and $\mathrm{FF}$ of $51.5 \%$. Hence, the highest PCE of $2.9 \%$ is obtained for the $\mathrm{TiO}_{2} / \mathrm{C}_{60}-\mathrm{NS} / \mathrm{CdS}$ cell. The solar cell parameters are given in Table S4. $\dagger$

IPCE versus wavelength plots of the cells with three photoanodes and with two different CEs are displayed in Fig. 7d and e. For a cell with a given photoanode, IPCEs of cells with $\mathrm{MoS}_{2}$ / C-cloth CEs are higher than the IPCEs of cells with C-cloth as CEs. $\mathrm{A} \mathrm{TiO}_{2} / \mathrm{CdS}$ cell exhibits a maximum IPCE of $32.4 \%$ at $\lambda=$ $410 \mathrm{~nm}$ with $\mathrm{MoS}_{2} / \mathrm{C}$-cloth as a CE. With C-cloth as a CE, the same shows a maximum IPCE of $25.3 \%$. By the inclusion of $\mathrm{C}_{60^{-}}$ $\mathrm{B}$, the IPCE of the cells with a $\mathrm{TiO}_{2} / \mathrm{C}_{60}-\mathrm{B} / \mathrm{CdS}$ photoanode and $\mathrm{MoS}_{2} / \mathrm{C}$-cloth and C-cloth CEs are increased to $48 \%$ and $43 \%$ respectively compared to $\mathrm{TiO}_{2} / \mathrm{CdS}$ based cells. The advantage of $\mathrm{MoS}_{2} / \mathrm{C}$-cloth as CE is directly reflected in the IPCE values. When $\mathrm{C}_{60}-\mathrm{NS}$ is used in the $\mathrm{TiO}_{2} / \mathrm{CdS}$ photoanode, the maximum IPCE is $67.5 \%$, which is the highest IPCE among all the photoanodes (with a $\mathrm{MoS}_{2} / \mathrm{C}$-cloth $\mathrm{CE}$ ). Compared to this, the $\mathrm{TiO}_{2} / \mathrm{C}_{60}-\mathrm{NS} / \mathrm{CdS}$ cell with a C-cloth $\mathrm{CE}$ shows lower IPCE values of $60 \%$. The superior ability of $\mathrm{C}_{60}-\mathrm{NS}$ to transport electrons is the reason for higher current efficiency among all cells.

Fig. $7 \mathrm{f}-\mathrm{i}$ show the outcome of the stability test for the best cell assembly of $\mathrm{TiO}_{2} / \mathrm{C}_{60}-\mathrm{NS} / \mathrm{CdS}$ photoanode and $\mathrm{MoS}_{2} / \mathrm{C}$-cloth
$\mathrm{CE}$, and a polysulfide gel as the electrolyte. The cell is stored in open (under simulated sunlight). The $J-V$ characteristics of the cell were measured at every $100 \mathrm{~min}$ interval and the solar cell parameters are given in Table S5. $\dagger$ Prior to each measurement, the polysulfide electrolyte was replenished. When the cell was measured for the first time, it shows a $J_{\mathrm{SC}}$ of $15.5 \mathrm{~mA} \mathrm{~cm} \mathrm{~cm}^{-2}$. Gradually, the $J_{\mathrm{SC}}$ decreases to $12.9 \mathrm{~mA} \mathrm{~cm}^{-2}$, after $100 \mathrm{~min}$. In comparison, the $V_{\text {OC }}$, initially and at $100 \mathrm{~min}$, is almost the same. Surprisingly, on increasing exposure time, from 200 to $400 \mathrm{~min}$, the $V_{\mathrm{OC}}$ increases. This could be due to better penetration of the gel across the cross-section of the photoanode and the CE, with time. At $500 \mathrm{~min}$, the decrease in $V_{\text {OC }}$ is minimal. FF also progressively increases with time, possibly due to the increase in photovoltage. PCE is nearly constant upto $200 \mathrm{~min}$. It decreases by not a great degree, at $500 \mathrm{~min}$, due to the decrease in $J_{\mathrm{SC}}$.

\subsection{EIS studies on QDSCs}

EIS studies were performed on QDSCs and the data was analysed with a standard model (Fig. 8). ${ }^{39-41}$ EIS spectra was recorded for the three photoanodes $\left(\mathrm{TiO}_{2} / \mathrm{C}_{60}-\mathrm{NS} / \mathrm{CdS}, \mathrm{TiO}_{2} / \mathrm{C}_{60}-\mathrm{B} /\right.$ $\mathrm{CdS}$ and $\mathrm{TiO}_{2} / \mathrm{CdS}$ ) using the same $\mathrm{CE}$ : $\mathrm{MoS}_{2} / \mathrm{C}$-cloth using polysulfide gel electrolyte under dark conditions at different magnitudes of forward bias ranging from -0.3 to $-0.75 \mathrm{~V}$. Two skewed semicircles are observed in the Nyquist plots. The first semicircle in the high frequency region (first semicircle) is due to electron transport resistance through $\mathrm{TiO}_{2}$ and the second semicircle at intermediate frequency (second semicircle) region corresponds to charge transfer from photoanode to electrolyte. Nyquist plot was described through transmission line circuit. From Nyquist plots, EIS parameters such as chemical capacitance $\left(C_{\mu}\right)$, recombination resistance $\left(R_{\text {rec }}\right)$, transport resistance $\left(R_{\mathrm{t}}\right)$ and dark current were determined, and plotted as a function of applied bias. $C_{\mu}$ is the electron density at Fermi level of $\mathrm{TiO}_{2} . R_{\text {rec }}$ is the resistance offered to excited electron-oxidized polysulfide recombination at the photoanode/electrolyte interface. $R_{\mathrm{t}}$ is the resistance offered by the photoanode to electron injection to FTO. Fig. 8a shows the plot for chemical

Table 2 Solar cell parameters of QDSCs containing $1 \mathrm{M} \mathrm{Na}_{2} \mathrm{~S}+1 \mathrm{M}$ S polysulfide based gel electrolyte under 1 sun illumination (AM 1.5, 100 mW $\mathrm{cm}^{-2}$ )

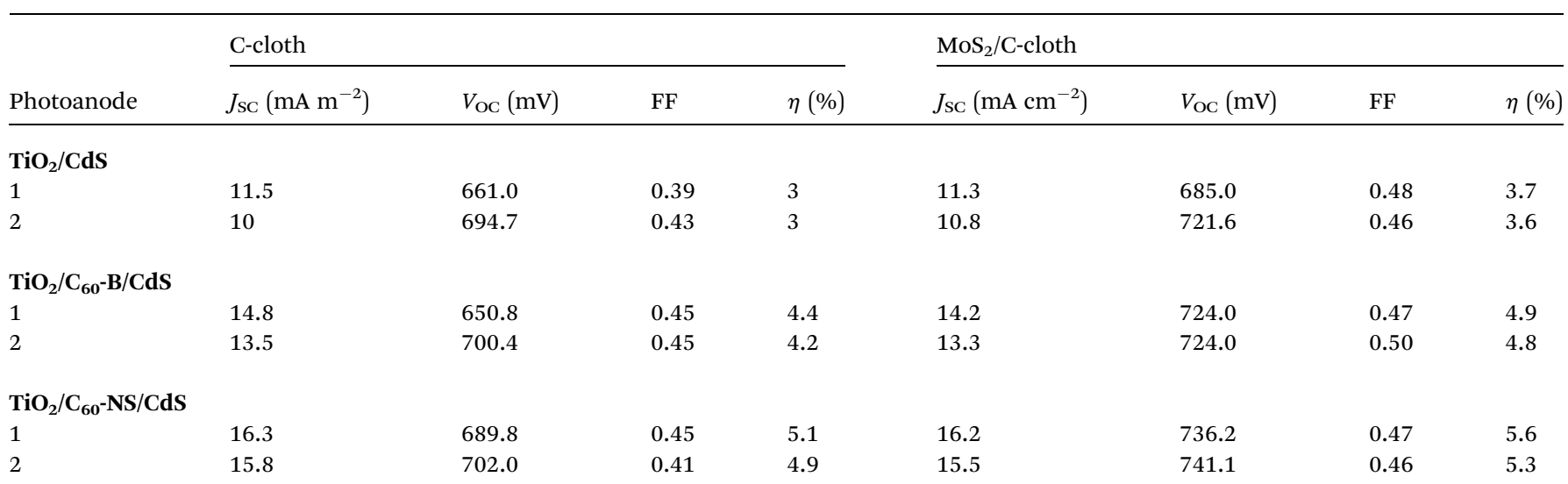



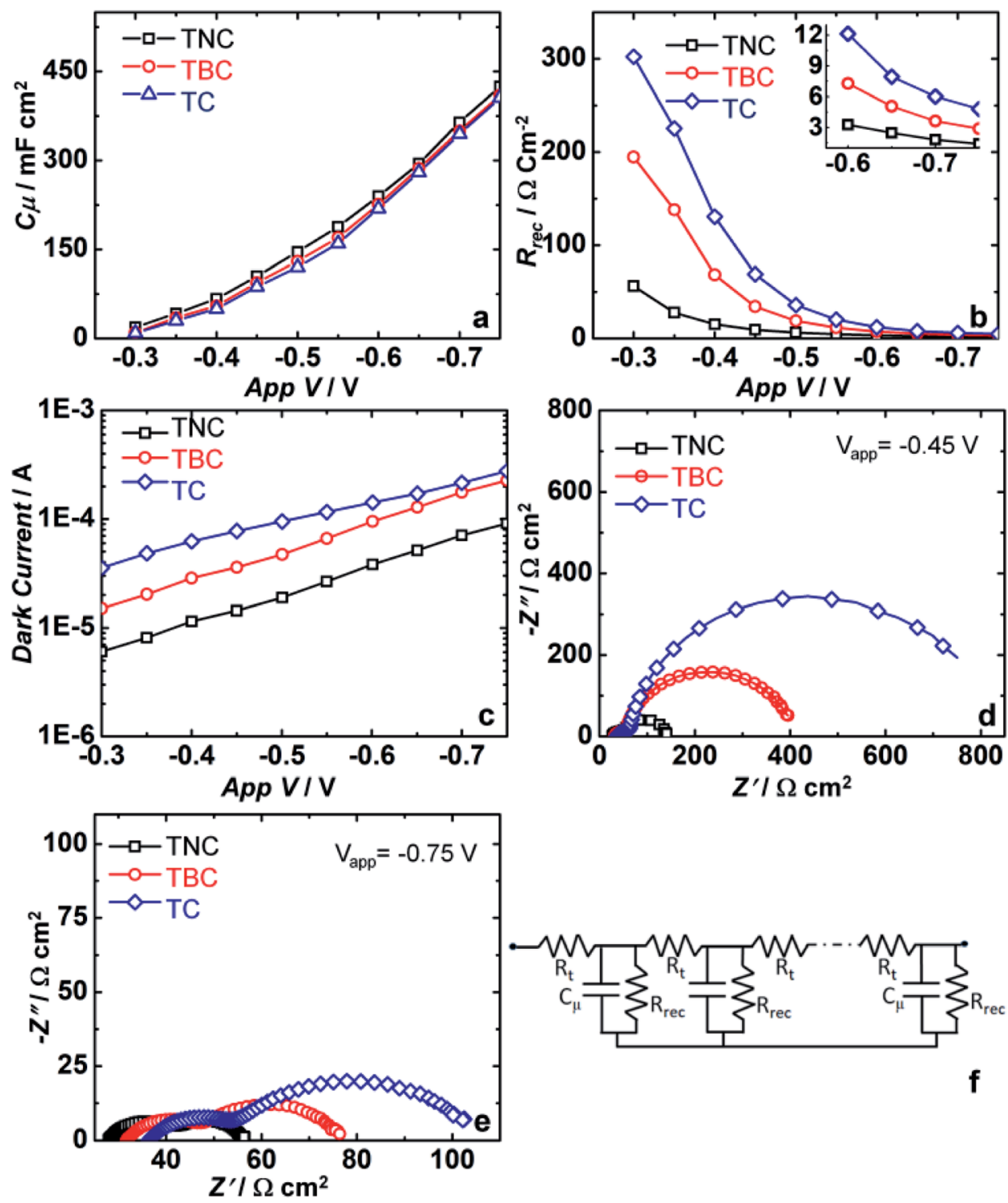

Fig. 8 (a) ElS characterization of different photoanodes $\mathrm{TiO}_{2} / \mathrm{CdS}(\mathrm{TC}), \mathrm{TiO}_{2} / \mathrm{C}_{60}-\mathrm{B} / \mathrm{CdS}$ (TBC) and $\mathrm{TiO}_{2} / \mathrm{C}_{60}-\mathrm{NS} / \mathrm{CdS}$ (TNC): (a) $\mathrm{C}_{\mu \prime}$ (b) $R_{\mathrm{rec}}$ (c) dark current as a function of applied voltages, (d) and (e) Nyquist plots at $-0.45 \mathrm{~V}$ and $-0.75 \mathrm{~V}$ and (f) is a transmission line circuit.

capacitance versus applied voltage. For all photoanodes, $C_{\mu}$ increases with increasing applied voltage. At $-0.45 \mathrm{~V}$ and $-0.75 \mathrm{~V}, C_{\mu}$ for the $\mathrm{C}_{60}$-NS based cell are 10.5 and $42.5 \mathrm{mF} \mathrm{cm}^{-2}$. $C_{\mu}$ for $\mathrm{TiO}_{2} / \mathrm{C}_{60}-\mathrm{NS} / \mathrm{CdS}$ cell is higher than that for the $\mathrm{TiO}_{2} / \mathrm{C}_{60^{-}}$ $\mathrm{B} / \mathrm{CdS}$ and $\mathrm{TiO}_{2} / \mathrm{CdS}$ cell. Fig. 8b shows the variation of $R_{\text {rec }}$ with applied voltage. $R_{\text {rec }}$ is decreasing with increased applied bias and $R_{\text {rec }}$ for $\mathrm{TiO}_{2} / \mathrm{C}_{60}-\mathrm{NS} / \mathrm{CdS}$ cell was lower than the other two cells. The reason is unclear. Dark current decreases with increasing voltage (Fig. 8c). For $\mathrm{C}_{60}$-NS based cell, the dark current is the least. From Fig. 8d and e it is observed that as it is observed a gradual decreased impedance as the applied voltage increases.

In the high frequency region, a $45^{\circ}$ slant is observed at the commencement of the first semi-circle, which is representative of the electron diffusion through the $\mathrm{TiO}_{2}$ film. This line is one third of the transport resistance $\left(R_{\mathrm{t}} / 3\right)$. Electrical conductivity can be determined from the transport resistance value i.e. $\sigma=$
$R_{\mathrm{t}} / L$, where $L$ is the thickness of film. At $-0.75 \mathrm{~V}, R_{\mathrm{t}}$ of $\mathrm{TiO}_{2} / \mathrm{CdS}$, $\mathrm{TiO}_{2} / \mathrm{C}_{60}-\mathrm{B} / \mathrm{CdS}$ and $\mathrm{TiO}_{2} / \mathrm{C}_{60}-\mathrm{NS} / \mathrm{CdS}$ based cells are $0.8,0.74$ and $0.54 \Omega \mathrm{cm}^{2}$ respectively (Table 3 ). In the $\mathrm{C}_{60}-\mathrm{NS}$ based cell, electron transport to FTO via $\mathrm{TiO}_{2}$ is more facile compared to the other two cells.

\subsection{Performance of integrated device (QDSC and supercapacitor)}

The $\mathrm{TiO}_{2} / \mathrm{C}_{60}-\mathrm{NS} / \mathrm{CdS}-\mathrm{S}^{2-} / \mathrm{S}-\mathrm{MoS}_{2}$ based quantum dot solar cell is integrated with the $\mathrm{MoS}_{2} / / \mathrm{MoS}_{2}$ symmetric supercapacitor supported over C-cloth current collectors, by electrically connecting the two cells. The solar cell comprises of $\mathrm{TiO}_{2} / \mathrm{C}_{60}-\mathrm{NS} /$ $\mathrm{CdS}$ as photoanode, $\mathrm{MoS}_{2} / \mathrm{C}$-cloth as $\mathrm{CE}$ with a polysulfide gel electrolyte, whereas the supercapacitor contains two electrodes of $\mathrm{MoS}_{2} / \mathrm{C}$-cloth separated by an aqueous $\mathrm{KCl}$ electrolyte in a symmetric configuration. The two cells are also connected to 
Table 3 EIS parameters obtained from Nyquist plots of QDSCs

\begin{tabular}{|c|c|c|c|c|c|c|}
\hline Photoanode & \multicolumn{3}{|l|}{$-0.45 \mathrm{~V}$} & \multicolumn{3}{|l|}{$-0.75 \mathrm{~V}$} \\
\hline $\mathrm{TiO}_{2} / \mathrm{C}_{60}-\mathrm{B} / \mathrm{CdS}$ & 1.5 & 341.8 & 9.4 & 0.74 & 28.9 & 41 \\
\hline $\mathrm{TiO}_{2} / \mathrm{C}_{60}-\mathrm{NS} / \mathrm{CdS}$ & 1 & 92.9 & 10.5 & 0.54 & 14 & 42.5 \\
\hline
\end{tabular}

the potentiostat in a two electrode mode for measurements. A schematic and a photograph for the integrated device are shown in Fig. 9a and b. The solar cell of the integrated device is exposed to 1 sun illumination for $1 \mathrm{~min}$ and during this time, the voltage response of the supercapacitor is measured as function of time. The plot is shown in Fig. 9c.

Upon illumination, the photocurrent produced by the solar cell is channeled to the $\mathrm{MoS}_{2}$ electrode of the supercapacitor. As anticipated, the $\mathrm{MoS}_{2}$ electrodes of the supercapacitor get photo-charged, as the voltage of the cell shows an abrupt increase from 0 to $0.7 \mathrm{~V}$, and this voltage remains almost constant for the duration (of $\sim 1 \mathrm{~min}$ ) for which the cell is illuminated. During this process, no current or voltage was applied to the supercapacitor or the solar cell from any external source, thus clearly illustrating that the supercapacitor is charged solely by the photocurrent generated by the solar cell, under irradiance. Upon switching off the light, and by applying an external current density of $3 \mathrm{~A} \mathrm{~g}^{-1}$ to the supercapacitor, the supercapacitor discharged to $\sim 0 \mathrm{~V}$ in $40 \mathrm{~s}$. $\mathrm{SC}$ is found to be $171.4 \mathrm{~F} \mathrm{~g}^{-1}$ for the integrated device which is lower than the SC achieved for the sole supercapacitor. This could be due to the lower $\Delta V$, and due to some (yet unclear) losses.

The energy density and the power density are 11.6 $\mathrm{W} \mathrm{h} \mathrm{kg}^{-1}$ and $1 \mathrm{~kW} \mathrm{~kg}^{-1}$ respectively. This performance reveals the capability of $\mathrm{MoS}_{2}$ to store the energy of solar cell in the supercapacitor. Fig. 9d shows the self-discharge process of the integrated device. Again, the device was charged to $0.7 \mathrm{~V}$ by exposure to 1 sun illumination for $1 \mathrm{~min}$. After switching off the light, and by applying zero current or bias, the discharge process is monitored. The voltage readily reduced to a constant voltage of $0.25 \mathrm{~V}$ which is preserved retained for $200 \mathrm{~s}$. This again shows that the device is capable of storing charge for reasonable durations.

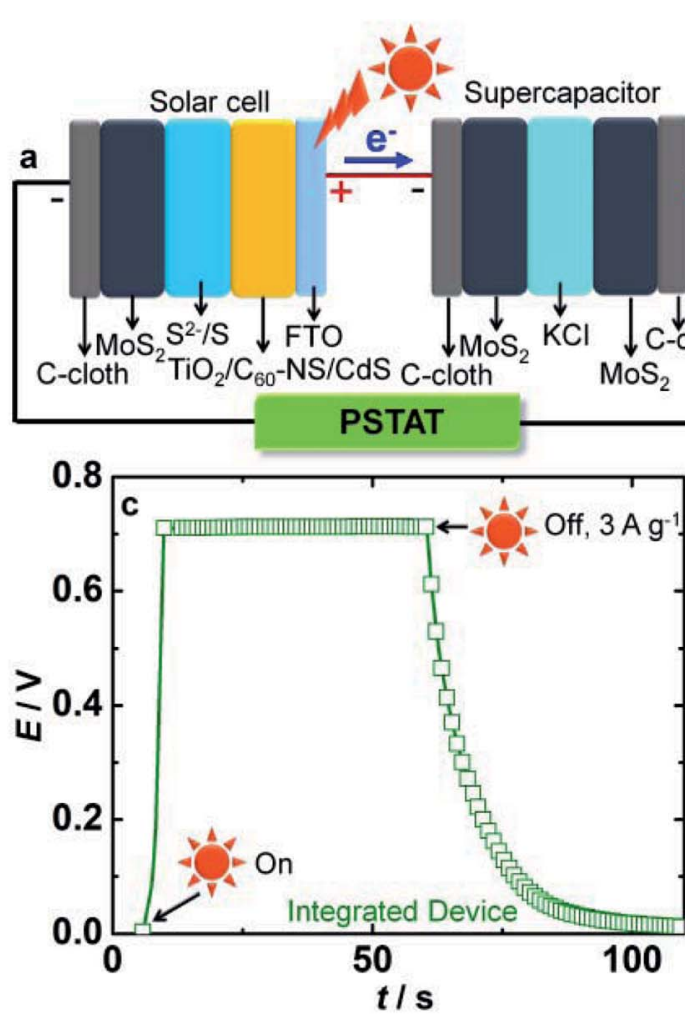

b
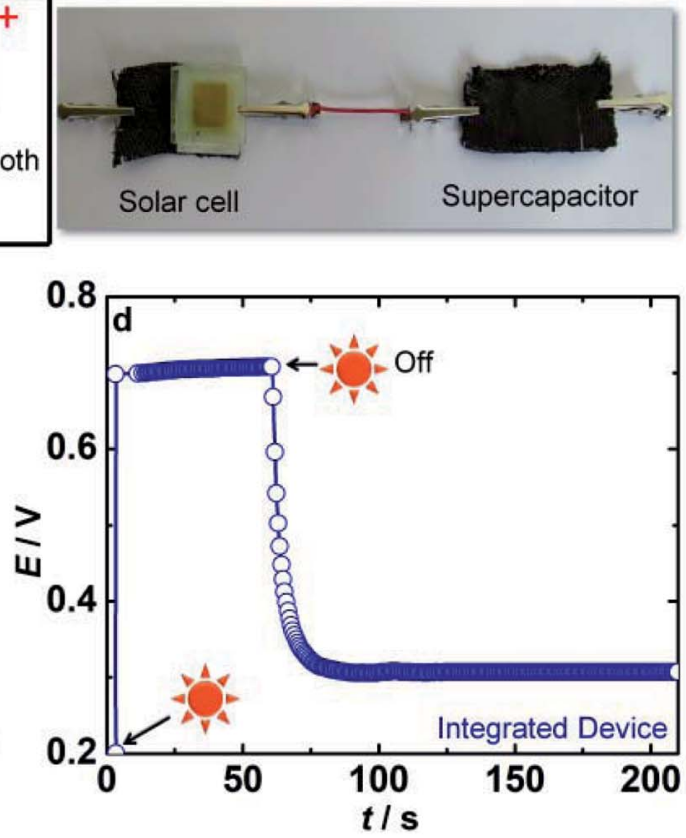

Fig. 9 (a) Schematic and (b) photograph of the integrated device. (c) Photo-charging and discharge characteristics of an integrated device. Photo-charging is done under 1 sun illumination $\left(100 \mathrm{~mW} \mathrm{~cm}^{-2}\right.$ ) for 1 min followed by discharge under dark at $3 \mathrm{~A} \mathrm{~g}^{-1}$. (d) Self-discharge plot (under zero bias or current) obtained after photo-charging the integrated device. 


\section{Conclusions}

A QDSC with a $\mathrm{TiO}_{2} / \mathrm{C}_{60}-\mathrm{NS} / \mathrm{CdS}$ photoanode and a $\mathrm{MoS}_{2} / \mathrm{C}$-cloth $\mathrm{CE}$ is fabricated and characterized. $\mathrm{C}_{60}-\mathrm{NS}$ have hexagonalshapes and crystal structure, and they are more electrically conducting compared to bulk $\mathrm{C}_{60}\left(\mathrm{C}_{60}-\mathrm{B}\right)$, perhaps due to their unique morphology. $\mathrm{C}_{60}$-NS have a deeper work function than $\mathrm{C}_{60}-\mathrm{B}$ with respect to vacuum level, and due to this suitably poised energy level and higher conductance, $\mathrm{C}_{60}$-NS also allow faster excited electron (from the $\mathrm{CB}$ of $\mathrm{CdS}$ ) depopulation compared to $\mathrm{C}_{60}-\mathrm{B}$, when used in a $\mathrm{TiO}_{2} / \mathrm{CdS}$ assembly. Besides the use of $\mathrm{C}_{60}$-NS in the photoanode for the first time, which leads to improved photovoltaic performance for the $\mathrm{TiO}_{2} / \mathrm{C}_{60^{-}}$ NS/CdS compared to the $\mathrm{TiO}_{2} / \mathrm{C}_{60}-\mathrm{B} / \mathrm{CdS}$ and $\mathrm{TiO}_{2} / \mathrm{CdS}$ based cells, irrespective of the $\mathrm{CE}$ used, the potential of $\mathrm{MoS}_{2} / \mathrm{C}$-cloth as a CE for QDSCs was also unravelled. $\mathrm{MoS}_{2}$ on C-cloth, resulted in improved electrocatalytic activity and lower charge transfer resistance for polysulfide reduction at the $\mathrm{CE} /$ electrolyte interface relative to pristine C-cloth. The higher electrical conductivity and a work function of $4.6 \mathrm{eV}$ deduced for the $\mathrm{MoS}_{2} / \mathrm{C}$-cloth electrode, also favors faster electron injection into the oxidized electrolyte during cell operation, compared to C-cloth. The champion cell with the $\mathrm{TiO}_{2} / \mathrm{C}_{60}-\mathrm{NS} / \mathrm{CdS}$ photoanode and $\mathrm{a} \mathrm{MoS}_{2} / \mathrm{C}$-cloth $\mathrm{CE}$, delivers a PCE of $5.6 \%$, greater than that produced by the cells with $\mathrm{TiO}_{2} / \mathrm{C}_{60}-\mathrm{B} / \mathrm{CdS}$ and $\mathrm{TiO}_{2} /$ CdS photoanodes. With C-cloth as CE, the PCE of the $\mathrm{TiO}_{2} / \mathrm{C}_{60^{-}}$ NS/CdS photoanode based cell drops to $5.13 \%$, illustrating the $\mathrm{MoS}_{2}$ effect. These studies show how promising $\mathrm{C}_{60}$-NS and $\mathrm{MoS}_{2}$ are in ameliorating the performance of QDSCs. The energy storage performance of the $\mathrm{MoS}_{2} / \mathrm{C}$-cloth electrode was also evaluated by using it in a symmetric supercapacitor cell. The highest specific capacitance achieved by the $\mathrm{MoS}_{2} / \mathrm{C}$-cloth cell is $645 \mathrm{~F} \mathrm{~g} \mathrm{~g}^{-1}$ at $2 \mathrm{~A} \mathrm{~g}^{-1}$ current density, and the cell also showed rectangular cyclic voltammetric profile over a voltage window of $1.2 \mathrm{~V}$. The $\mathrm{MoS}_{2} / \mathrm{C}$-cloth electrode thus not only functions as an efficient CE for energy harvesting, but it is also a potential candidate for energy storage. By integrating the $\mathrm{MoS}_{2}$ supercapacitor with the QDSC, the resulting device was charged to $0.7 \mathrm{~V}$, under 1 sun irradiance, without any other external bias or current.

\section{Conflicts of interest}

There is no conflict of interest.

\section{Acknowledgements}

Financial support from the Department of Science \& Technology of India (Project: India-UK Center for education and research in clean energy (IUCERCE)), grant no (DST/RCUK/ JVCCE/2015/04(1)(G)) is gratefully acknowledged.

\section{References}

1 S. Jiao, J. Du, Z. Du, D. Long, W. Jiang, Z. Pan, Y. Li and X. Zhong, J. Phys. Chem. Lett., 2017, 8, 559-564.
2 W. Wang, W. Feng, J. Du, W. Xue, L. Zhang, L. Zhao, Y. Li and X. Zhong, Adv. Mater., 2018, 30, 1705746.

3 P. V. Kamat, J. Phys. Chem. C, 2008, 112, 18737-18753.

4 P. N. Kumar, S. Mandal, M. Deepa, A. K. Srivastava and A. G. Joshi, J. Phys. Chem. C, 2014, 118, 18924-18937.

5 R. Narayanan, M. Deepa and A. K. Srivastava, Phys. Chem. Chem. Phys., 2012, 14, 767-778.

6 L. H. Lai, L. Protesescu, M. V Kovalenko and M. a. Loi, Phys. Chem. Chem. Phys., 2014, 16, 736-742.

7 P. K. Santra, P. V. Nair, K. G. Thomas and P. V. Kamat, J. Phys. Chem. Lett., 2013, 4, 722-729.

8 K. Zhao, Z. Pan, I. Mora-Sero, E. Canovas, H. Wang, Y. Song, X. Gong, J. Wang, M. Bonn, J. Bisquert and X. Zhong, J. Am. Chem. Soc., 2015, 137, 5602-5609.

9 C. V. V. M. Gopi, M. V. Haritha, S. Kim and H. Kim, Nanoscale, 2015, 7, 12552-12563.

10 Z. Ren, J. Wang, Z. Pan, K. Zhao, H. Zhang, Y. Li, Y. Zhao, I. Mora-Sero, J. Bisquert and X. Zhong, Chem. Mater., 2015, 27, 8398-8405.

11 J. Yang, J. Wang, K. Zhao, T. Izuishi, Y. Li, Q. Shen and X. Zhong, J. Phys. Chem. C, 2015, 119, 28800-28808.

12 W. Peng, J. Du, Z. Pan, N. Nakazawa, J. Sun, Z. Du, G. Shen, J. Yu, J. Hu, Q. Shen and X. Zhong, ACS Appl. Mater. Interfaces, 2017, 9, 5328-5336.

13 X. Miao, S. Tongay, M. K. Petterson, K. Berke, A. G. Rinzler, B. R. Appleton and A. F. Hebard, Nano Lett., 2012, 12, 27452750.

14 R. Narayanan, B. N. Reddy and M. Deepa, J. Phys. Chem. C, 2012, 116, 7189-7199.

15 S. Muduli, W. Lee, V. Dhas, S. Mujawar, M. Dubey, K. Vijayamohanan, S. H. Han and S. Ogale, ACS Appl. Mater. Interfaces, 2009, 1, 2030-2035.

16 P. V. Kamat, M. Haria and S. Hotchandani, J. Phys. Chem. B, 2004, 108, 5166-5170.

17 H. Xin, O. G. Reid, G. Ren, F. S. Kim, D. S. Ginger and S. A. Jenekhe, ACS Nano, 2010, 4, 1861-1872.

18 Y. Li, L. Zhao, Z. Du, J. Du, W. Wang, Y. Wang, L. Zhao, X. Cao and X. Zhong, J. Mater. Chem. A, 2018, 6, 2129-2138.

19 L. Zhao, L. Zhao, W. Xue, W. fang, Y. Wang and Y. Li, Sol. Energy, 2018, 169, 505-511.

20 C. V. V. M. Gopi, M. V. Haritha, S. Kim and H. Kim, J. Power Sources, 2016, 311, 111-120.

21 C. V. V. M. Gopi, S. Singh, A. E. Reddy and H. Kim, ACS Appl. Mater. Interfaces, 2018, 10, 10036-10042.

22 C. V. V. M. Gopi, M. V. Haritha, Y. Lee and H. Kim, J. Mater. Chem. A, 2016, 4, 8161-8171.

23 C. V. V. M. Gopi, S. Ravi, S. S. Rao, A. E. Reddy and H. Kim, Sci. Rep., 2017, 7, 46519.

24 C. V. V. M. Gopi, A. E. Reddy and H. Kim, J. Mater. Chem. A, 2018, 6, 7439-7448.

25 J. Xie, J. Zhang, S. Li, F. Grote, X. Zhang, H. Zhang, R. Wang, Y. Lie, B. Pan and Y. Xie, J. Am. Chem. Soc., 2017, 135, 1788117888.

26 D. Barpuzary, A. Banik, G. Gogoia and M. Qureshi, J. Mater. Chem. A, 2015, 3, 14378-14388.

27 B. Lei, G. R. Li and X. P. Gao, J. Mater. Chem. A, 2014, 2, 39193925. 
28 S.-Y. Tai, C.-J. Liu, S.-W. Chou, F. S.-S. Chien, J.-Y. Lin and T.-W. Lin, J. Mater. Chem., 2012, 22, 24753-24759.

29 M. Seol, D. H. Youn, J. Y. Kim, J.-W. Jang, M. Choi, J. S. Lee and K. Yong, Adv. Energy Mater., 2014, 4, 1300775.

30 G. Ma, H. Peng, J. Mu, H. Huang, X. Zhou and Z. Lei, J. Power Sources, 2013, 229, 72-78.

31 K.-J. Huang, L. Wang, Y. J. Liu, H. B. Wang, Y. M. Liu and L.-L. Wang, Electrochim. Acta, 2013, 109, 587-594.

32 K.-J. Huang, L. Wang, Y.-J. Liu, Y.-M. Liu, H.-B. Wang, T. Gan and L.-L. Wang, Int. J. Hydrogen Energy, 2013, 38, 1402714034.

33 M. Sathish and K. Miyazawa, J. Am. Chem. Soc., 2007, 129, 13816-13817.

34 H. Yu, X. Yu, Y. Chen, S. Zhang, P. Gao and C. Li, Nanoscale, 2015, 7, 8731-8738.

35 M. Sathish and K. Miyazawa, Molecules, 2012, 17, 3858-3865.
36 M. C. Martin, D. Koller, A. Rosenberg, C. Kendziora and L. Mihaly, Phys. Rev. B, 1995, 51, 3210-3213.

37 S. Leach, M. Vervloet, A. Despres, E. Breheret, J. P. Hare, T. J. Dennis, H. W. Kroto, R. Taylor and D. R. M. Walton, Chem. Phys., 1992, 160, 451-466.

38 R. N. Bulakhe, V. N. Nguyen and J. J. Shim, New J. Chem., 2017, 41, 1473-1482.

39 V. Gonzalez-Pedro, X. Xu, I. Mora-Sero and J. Bisquert, ACS Nano, 2010, 4, 5783-5790.

40 J. Wang, I. Mora-Sero, Z. Pan, K. Zhao, H. Zhang, Y. Feng, G. Wang, X. Zhong and J. Bisquert, J. Am. Chem. Soc., 2013, 135, 15913-15922.

41 I. Mora-Sero, S. Gimenez, F. Fabregat-Santiago, R. Gomez, Q. Shen, T. Toyoda and J. Bisquert, Acc. Chem. Res., 2009, 42, 1848-1857. 